\title{
Tectonics
}

\author{
RESEARCH ARTICLE \\ 10.1029/2018TC005422 \\ Key Points: \\ - From new and previous gravity data, \\ we constructed Bouguer anomaly \\ and residual Bouguer anomaly maps \\ across the Linking Zone \\ - Gravity data are used to constrain \\ depth geometries across seven, \\ balanced cross sections \\ - Good correlation between residual \\ gravity anomalies and basement \\ geometries that are reconstructed \\ through 3-D gravity inversion
}

Correspondence to:

E. Izquierdo-Llavall,

eizquierdollavall@gmail.com;

esther.izquierdo-llavall@univ-pau.fr

Citation:

Izquierdo-Llavall, E., Ayala, C., Pueyo, E. L., Casas-Sainz, A. M., Oliva-Urcia, B., Rubio, F., et al. (2019).

Basement-cover relationships and their along-strike changes in the Linking Zone (Iberian Range, Spain): A combined structural and gravimetric study. Tectonics, 38, 2934-2960. https://doi. org/10.1029/2018TC005422

Received 18 NOV 2018 Accepted 10 JUL 2019 Accepted article online 16 JUL 2019 Published online 14 AUG 2019

(C)2019. American Geophysical Union. All Rights Reserved.

\section{Basement-Cover Relationships and Their Along-Strike Changes in the Linking Zone (Iberian Range, Spain): A Combined Structural and Gravimetric Study}

\author{
E. Izquierdo-Llavall ${ }^{1}$ (D) C. Ayala ${ }^{2,3}$, E. L. Pueyo ${ }^{4,5}$, A. M. Casas-Sainz ${ }^{5,6}$ (D), B. Oliva-Urcia ${ }^{7}$ (D), \\ F. Rubio ${ }^{2}$, A. Rodríguez-Pintó ${ }^{8}$, C. Rey-Moral ${ }^{2}$, J. F. Mediato ${ }^{2}$, and J. García-Crespo ${ }^{2}$ \\ ${ }^{1}$ E2S-UPPA, UPPA-CNRS-Total, Laboratoire des Fluides Complexes et leurs Réservoirs, IPRA, Université de Pau et des \\ Pays de l'Adour, Pau, France, ${ }^{2}$ Instituto Geológico y Minero de España (IGME), Madrid, Spain, ${ }^{3}$ Now at the Institute of \\ Earth Sciences Jaume Almera-CSIC, Barcelona, Spain, ${ }^{4}$ Instituto Geológico y Minero de España (IGME), Unidad de \\ Zaragoza, Zaragoza, Spain, ${ }^{5}$ Unidad Asociada en Ciencias de la Tierra IGME/Universidad de Zaragoza, Zaragoza, Spain, \\ ${ }^{6}$ Geotransfer Research Group (IUCA), Universidad de Zaragoza, Zaragoza, Spain, ${ }^{7}$ Departamento de Geología y \\ Geoquímica, Universidad Autónoma de Madrid, Madrid, Spain, ${ }^{8}$ Centro de Apoyo Científico y Tecnológico a la \\ Investigación, Universidad de Vigo, Vigo, Spain
}

Abstract Contractional deformation in the transition between the Iberian and Catalan Coastal Ranges (Linking Zone) generated both thin-skinned structures detached in low-strength Triassic units and basement-involved structures. To evaluate their extent and relative contribution to the overall structure, we carried out a study combining structural geology and gravimetry. New gravity data (938 stations) and density determinations (827 samples) were acquired and combined with previous existing databases to obtain Bouguer anomaly and residual Bouguer anomaly maps of the study area. Seven serial and balanced cross sections were built, their depth geometries being constrained through the 2.5-D gravity modeling and the 3-D gravity inversion that we accomplished. The residual Bouguer anomaly map shows a good correlation between basement antiforms and gravity highs whereas negative anomalies mostly correspond to (i) Meso-Cenozoic synclines and (ii) Neogene-Quaternary basins. Cross sections depict a southern, thick-skinned domain where extensional, basement faults inherited from Late Jurassic-Early Cretaceous times were inverted during the Cenozoic. To the north, we interpret the existence of both Triassic-detached and basement-involved deformation domains. The two deformation styles are vertically overlapped in the southernmost part of the Catalan Coastal Ranges but relay both across and along strike in the Eastern Iberian Range. These basement and cover relationships and their along-strike variations are analyzed in terms of the interplay between structural inheritance, its obliquity to the shortening direction, and the continuity and effectiveness of Triassic décollements in the study area.

\section{Introduction}

Thin-skinned and thick-skinned tectonics represent two end members of the structural styles recognized in fold-and-thrust belts (Pfiffner, 2006). Thin-skinned tectonics refers to thrust systems where the sedimentary cover is detached from the basement along a décollement that consists of mechanically weak rocks (Boyer \& Elliott, 1982; Butler, 1982; Mitra, 1986 among others). Conversely, thick-skinned tectonics relates to thrust faults that cut cover and basement units and may continue at depth as wider shear zones producing crustal thickening (Cook \& Varsek, 1994; De Vicente et al., 2007; De Vicente \& Vegas, 2009; Nemčok et al., 2013; Pfiffner, 2017). Halfway between these two end members, the term "basement-involved thin-skinned tectonics" refers to thrust systems that involve the few first kilometers of the basement (Pfiffner, 2006) and thus delimit relatively thin basement slices (Pfiffner, 2017). From a cover versus basement deformation point of view, these three structural styles can be divided into (i) basement-involved structures that include thick-skinned and basement-involved thin-skinned tectonics and (2) cover-detached structures, referring to "pure" thin-skinned tectonics where cover deformation is fully decoupled from the basement.

Basement-involved and cover-detached structures usually coexist in fold-and-thrust systems (FTSs) that encompass syncontractional or precontractional décollements: Basement-involved thrusting dominates in the innermost domains and transfers shortening to cover-detached FTSs that propagate toward the external zones (Figure 1a). Basement-involved and cover-detached deformation are thus roughly distributed within two across-strike domains that can partly overlap. Thrust spacing strongly depends on the thickness of the 


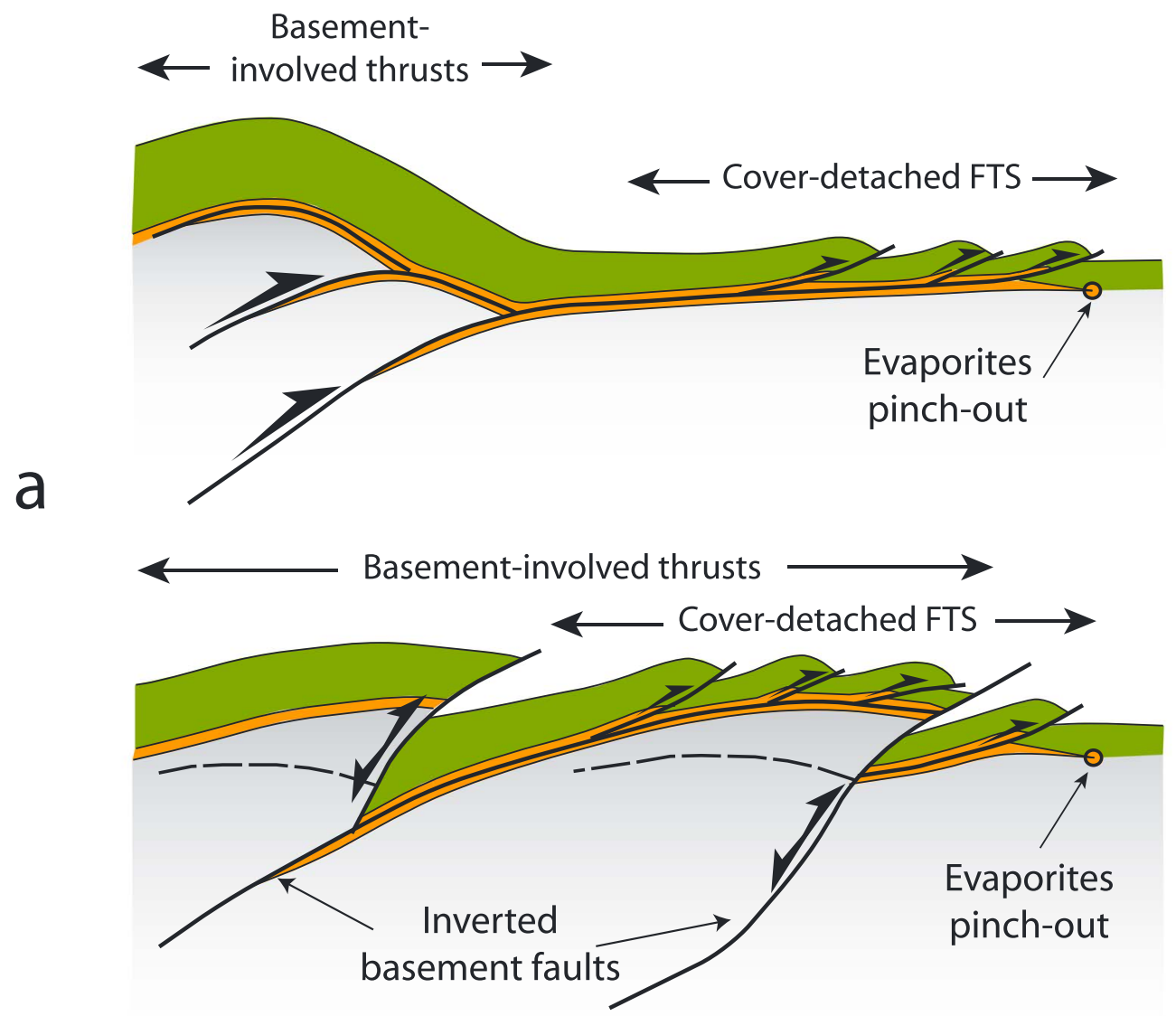

b

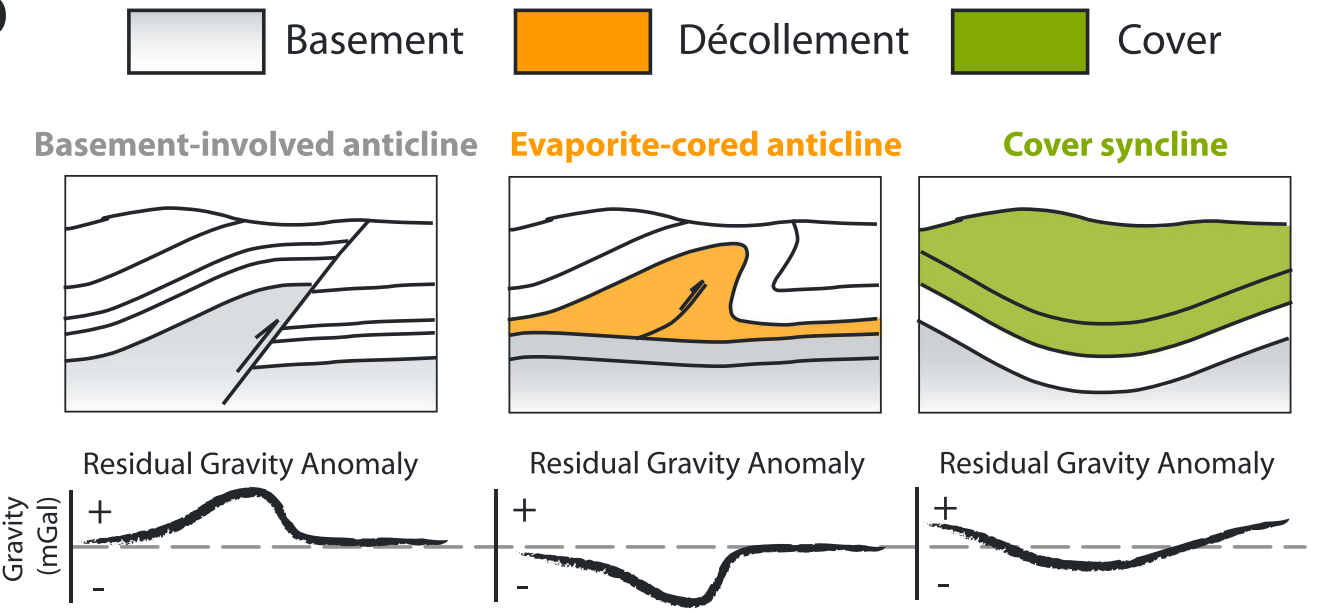

Figure 1. (a, b) Sketches showing cross-section distribution of basement-involved and cover-detached structures in a foldand-thrust system (FTS). The thrust system deforms a stratigraphic sequence that involves an interbedded weak décollement at the base of the sedimentary cover ( $\mathrm{a}$ and $\mathrm{b}$ ). In (b), the basement is affected by precontractional (and predécollement) extensional faults. Basement-involved structures in (a) involve the upper part of the basement and display long thrusts flats at a certain basement level (basement-involved thin-skinned tectonics). Conversely, basement faults in (b) are steeper and involve a thicker portion of the basement ("pure" thick-skinned tectonics). (c) Distinction of basement-, sedimentary-cover, and evaporite-cored folds through residual gravity anomaly data. Basement units are denser and thus produce positive residual gravity anomalies. Conversely, sedimentary cover units (including evaporites) are lighter and potentially lead to negative residual gravity anomalies. 
involved units (Huiqi et al., 1992), cover thrust sheets being thinner than basement-involved structures. This across-strike zoning has been widely documented in different fold-and-thrust belts such as the Pyrenees (Muñoz, 1992a), the Central Andes (Mégard, 1984), the Zagros (McQuarrie, 2004), or the Western Alps (Pfiffner, 2014).

This idealized distribution of basement-involved and cover-detached deformation in fold-and-thrust belts is modified where stratigraphic sequences are affected by inherited structures that predate contractional deformation (Figure 1b), such as basement anisotropies or compartmentalized extensional basins. In this scenario, inversion tectonics plays a key role in the final architecture of FTSs since structural inheritance largely controls the locus and orientation of inverted faults (Coward, 1994; De Graciansky et al., 1989; Williams et al., 1989).

Concurrence between inherited basement structures and the presence of weak, frequently evaporitic, décollements results in fold-and-thrust belts where basement-involved and cover-detached deformation domains overlap depending on (i) the location of previous structures and (ii) the lateral extent of the décollements. That is the case of fold-and-thrust belts such as the Atlas (Calvín et al., 2017; Teixell et al., 2003), the Iberian Range (De Vicente et al., 2009; Nebot \& Guimerà, 2016a, 2016b), or the Kuqa fold-andthrust belt in the southern Tian Shan (Izquierdo-Llavall et al., 2018). When this occurs, a main question arises: which of the structures that we observe at surface involve basement underneath and which of them are purely thin skinned, located above a flat basement, and cored by the evaporites that represent the décollement in the cover sequence?

To answer this question, a first approximation can be done through the building of balanced, regional cross sections in which shortening in the basement and in the cover must be equal. Second, and considering the significant contrast in the petrophysical properties (viz., density) of the rocks involved in deformation (basement, sedimentary cover or shale-type décollements, and evaporitic décollements), the role of basementinvolved and cover-detached structures can be evaluated, in an efficient and cost-effective way, through the use of potential field geophysics (Figure 1c). In this work, we propose a workflow that combines both techniques (construction of serial, balanced cross sections and gravity modeling) to better characterize deformation at depth to finally develop a reliable, 3-D structural model of the study area.

The target area is the Linking Zone (Guimerà, 1983, 1988), located in the transition between the Iberian Range and the Catalan Coastal Ranges (NE Spain). This FTS was formed during the Cenozoic and is characterized by strong, along-strike structural variations. It partly results from the inversion of a previous extensional basin, Late Jurassic-Early Cretaceous in age, and involves a low-strength precontractional décollement containing evaporites. Its structural complexity, together with the scarce knowledge of the subsurface (no seismic data and very few wells are available in the studied portion of the Linking Zone), makes it a challenging case study in order to test the suitability of our methodological approach for defining basement-cover relationships.

\section{Geological Setting}

\subsection{Regional Structure: The Iberian Range}

The Iberian Range is an intraplate range that extends from the Iberian Meseta to the Mediterranean Sea (Figure 2a). It laterally connects to the Catalan Coastal Ranges to the NE and to the Spanish-Portuguese Central System to the west and is bounded by the Cenozoic basins of the Ebro, Tagus, and Duero Rivers to the north, south, and west, respectively (Figures $2 \mathrm{a}$ and $2 \mathrm{~b}$ ). To the east and south, The Iberian Range transitions to the Valencia Trough extensional domain (Fontboté et al., 1990) and connects to the Betic Cordillera (Sanz de Galdeano, 1990), respectively.

The Iberian Range consists of a series of inverted Permian-Mesozoic basins and basement uplifts of Paleozoic (pre-Permian) rocks that were partly overlain by Cenozoic units (Alvaro et al., 1979; Salas \& Casas, 1993). Its present-day geometry is strongly controlled by structural inheritance: Variscan and LateVariscan structures in the Paleozoic basement on the one hand (Late Carboniferous to Permian in age) and Mesozoic extensional structures on the other. The latter resulted from two rifting cycles during Late Permian-Triassic and Late Jurassic-Early Cretaceous that were followed by postrift thermal subsidence stages (Salas et al., 2001). The first rifting stage (Late Permian-Triassic) favored the development of a 


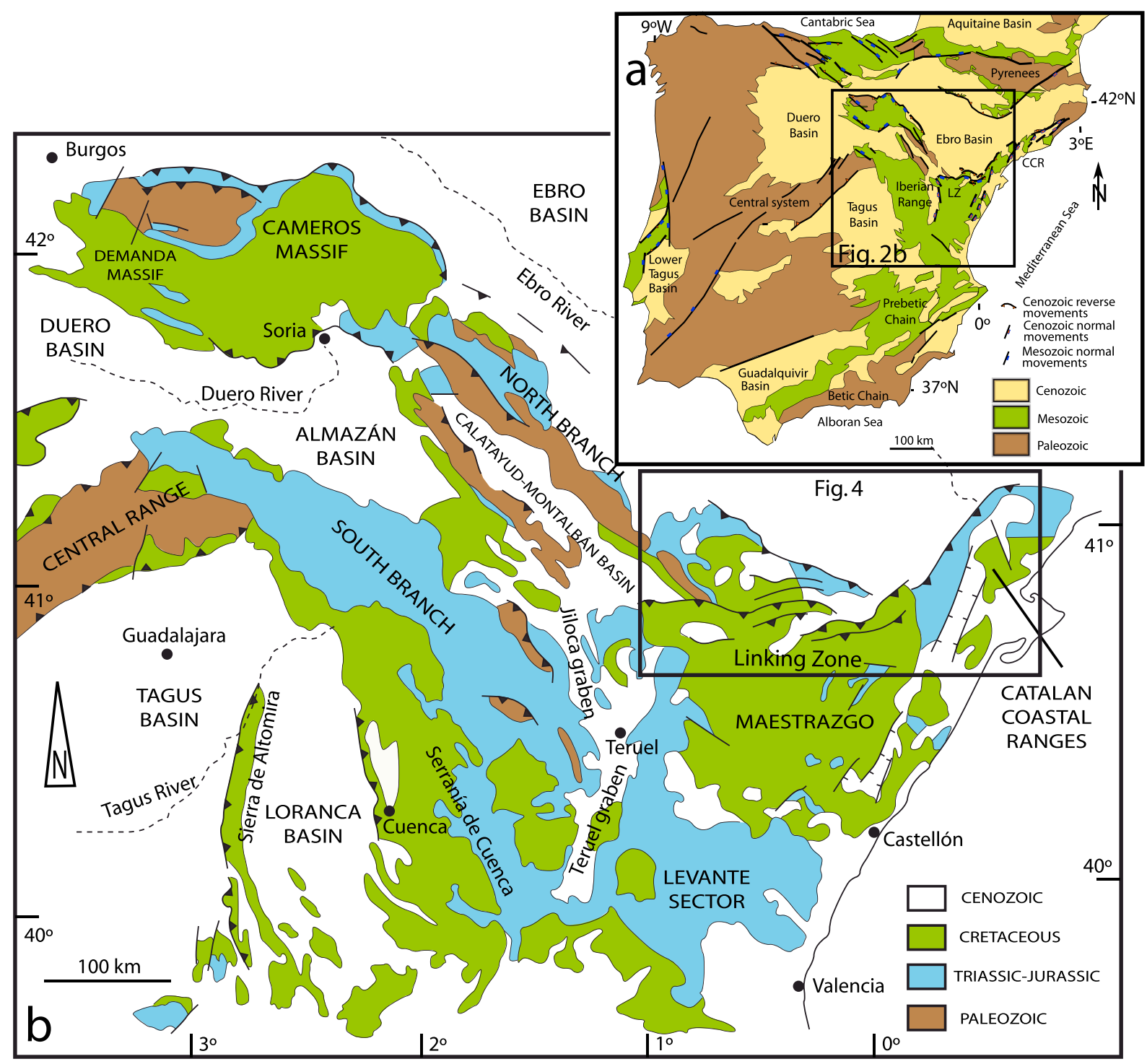

Figure 2. (a) Geological map of the Iberian Peninsula CCR = Catalan Coastal Ranges, LZ = Linking Zone. (b) Geological map of the Iberian Range (modified from Instituto Geológico y Minero de España, 2004) showing the location of the study area (black rectangle).

network of NE-SW and NW-SE trending basins in the Catalan Coastal and Iberian range domains, respectively (Arche \& López-Gómez, 1996). These basins host synrift sequences up to 1,200 m thick (Virgili et al., 1983) that recorded a switch from continental to marine and transitional environments, the latter including evaporitic sedimentation (Sopeña et al., 1988). During the second rifting stage, extension in the Iberian Range domain was mainly localized into two depocenters, the Cameros and Maestrazgo Basins (Figure 2b; Guimerà et al., 2004), where synrift units are up to 8,000 and 4,000 $\mathrm{m}$ thick and registered the onset of extension during Tithonian and Oxfordian times, respectively (Soria et al., 2000 and references therein). Synrift sequences range from shallow marine carbonates to deltaic, alluvial, and lacustrine units whose sedimentary distribution was controlled by NW-SE and NE-SW striking (and partly inherited) deep basement faults (Canérot, 1974; Guiraud \& Séguret, 1984; Roca et al., 1994; Salas \& Guimerà, 1997).

Mesozoic basins were inverted under compression during the Alpine period (late Eocene-early Miocene). The Cenozoic compression accounted for a total estimated shortening of $75 \mathrm{~km}$ that resulted in a thickened crustal domain beneath the Iberian Range (Salas et al., 2001). This shortening led to the inversion of inherited Permian-Triassic and Late Jurassic-Early Cretaceous faults as basement-involved, strike-slip, or reverseslip faults (De Vicente et al., 2009), whereas thin-skinned thrusting along Triassic evaporites took also place 


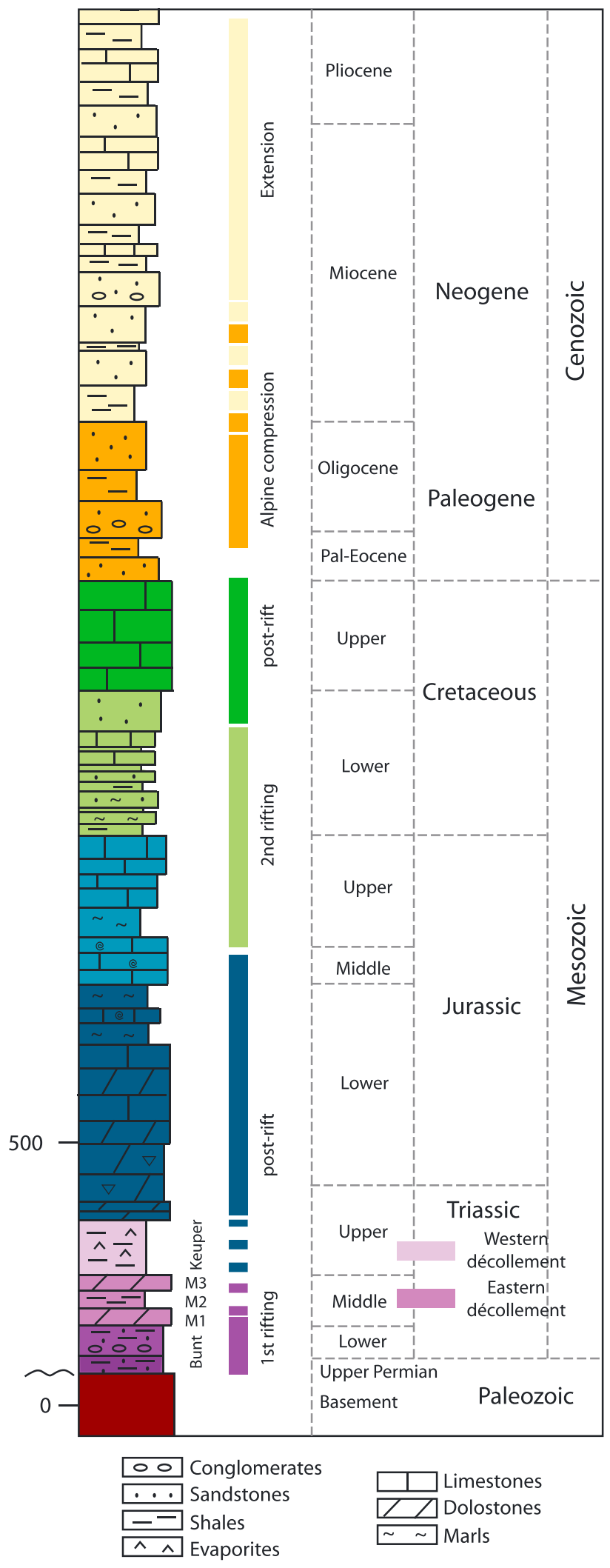

Figure 3. Stratigraphic sequence in the study area (modified from Casas et al., 1997). Main décollements and geodynamic context during deposition are indicated.
(Casas et al., 1997; Nebot \& Guimerà, 2016a, 2016b and references therein). Structural studies in the Iberian and Catalan Coastal Ranges (Casas-Sainz, 1992; Guimerà, 1988; Liesa, 2000; Liesa \& Simón, 2007) indicate a directional variability on Cenozoic fault transport and paleostress directions that has been explained using two different approximations. On the one hand, this variability can result from the superimposition of successive and partly coeval stress fields (Liesa \& Simón, 2007), namely, Iberian compression (NE-SW direction, from middle Eocene to late Oligocene), Betic compression (NW-SE direction, from early Eocene to the present day), and Pyrenean compression ( $\mathrm{N}$ to NNE direction, from Miocene to the present day). On the other hand, directional variability can also be explained by a single N-S compression event that, acting on inherited structures that are oblique to the shortening direction, produced strain partitioning and the occurrence of local stress deflections (Casas-Sainz, 1992; De Vicente, 2018; De Vicente et al., 2009; Guimerà, 1988). In the first scenario, the study area was mostly affected by the Iberian and Pyrenean stress fields (Liesa \& Simón, 2007) that average a NNE-SSW shortening direction. In the second scenario, the main tectonic transport direction in the study area was approximately $\mathrm{N} 010^{\circ} \mathrm{E}$ (De Vicente et al., 2009) and approximates the average inferred from the multiple-stage shortening model (Liesa \& Simón, 2007).

Contractional structures were partially dismantled, especially in the eastern part of the range, by an important net of NNE-SSW directed normal faults of Neogene age that are related to basin opening and crustal thinning in the Mediterranean domain (Alvaro et al., 1979; Anadón \& Moissenet, 1996; Roca \& Guimerà, 1992; Simón Gómez, 1984). These faults resulted, at least in the Catalan Coastal Ranges, from the inversion of previous syncompressional structures (Roca \& Guimerà, 1992) and at present are moderately active from the seismic point of view (Masana, 1994).

\subsection{Stratigraphy of the Study Area}

The stratigraphic sequence of the study area is mainly formed by sedimentary units ranging in age from Paleozoic to Cenozoic (Figure 3). Paleozoic outcrops are limited and markedly different in the Iberian Range (Montalbán and Puigmoreno anticlines, Figure 4) and the Catalan Coastal Ranges (Priorato anticline, Figure 4). Paleozoic units in the northern Iberian Range consist of Cambrian sandstones and shales and Lower Carboniferous turbidites (Culm facies) cut by Stephanian volcanic dykes and Permian alkaline volcanics (Almela-Samper et al., 1975; Canérot et al., 1977; Gutiérrez-Marco, 2004). Conversely, Paleozoic units in the Catalan Coastal Ranges are mostly formed by Carboniferous-Permian diorites, granodiorites, granites, and porphyry dykes and DevonianCarboniferous limestones, sandstones, conglomerates, and shales partly affected by contact metamorphism (Ayora et al., 1990; Crespo Ramón \& Michel, 1980; Enrique, 1990; Institut Cartogràtic i Geològic de Catalunya (ICGC), 2006; Julivert \& Durán, 1990; Orche-García et al., 1978). Unconformably lying on the Paleozoic, a typical Germanic type, Upper Permian-Triassic sequence was deposited (Arche \& LópezGómez, 1996; Sopeña et al., 1988), formed by (1) Upper-Permian-Lower Triassic red conglomerates, sandstones, siltstones, and shales (Buntsandstein Facies); (2) Middle Triassic dolostones and mudstones (Muschelkalk facies); and (3) Upper Triassic red and green shales with interbedded fine-grained sandstones and gypsum layers (Keuper facies). 


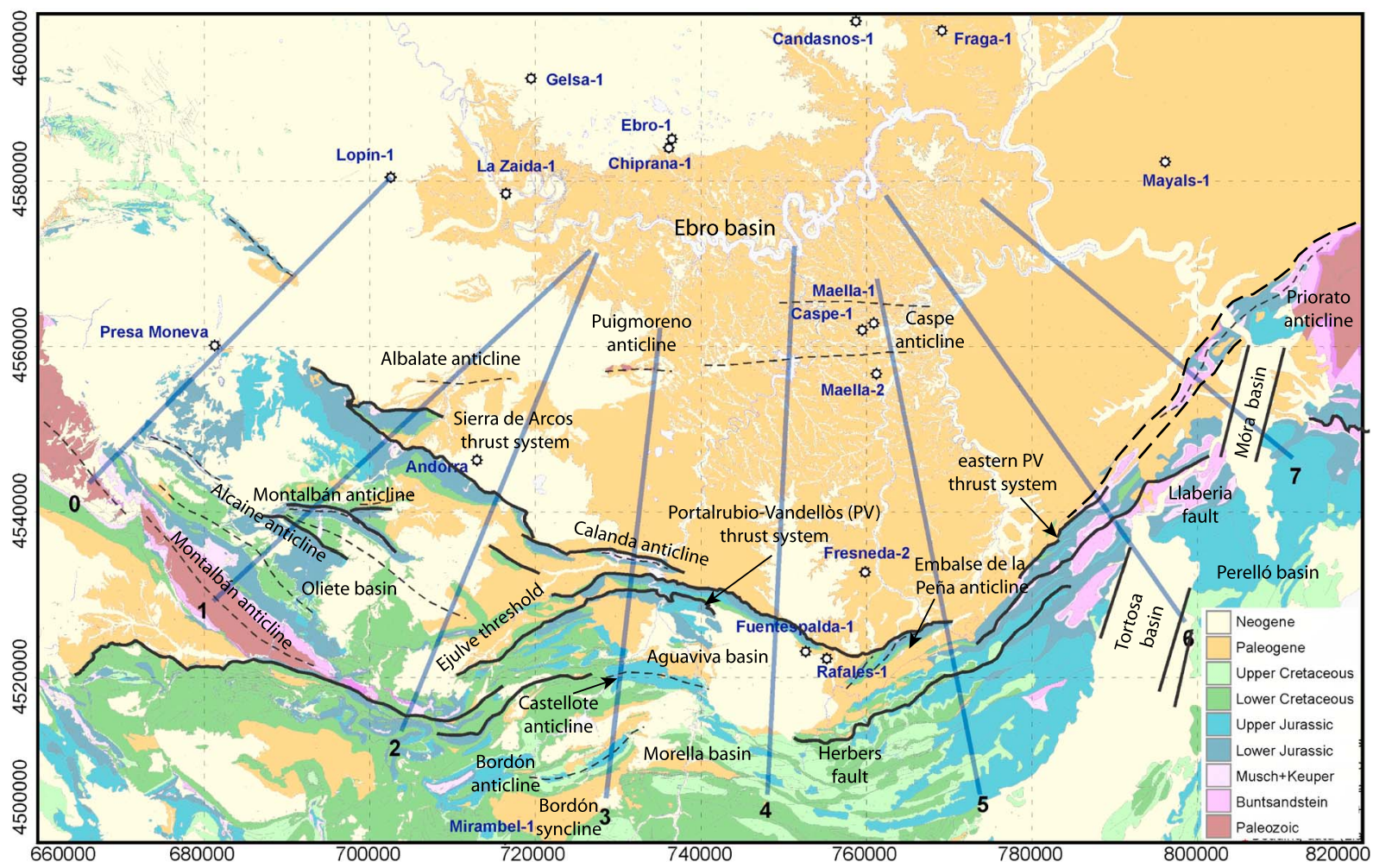

Figure 4. Geological map of the study area with location of the constructed cross sections and the available wells. Cross section 0 was schematically built and modeled to extend the mapping and 3-D modeling to the west, but the scarcity of surface information (the area is extensively covered by Miocene posttectonic units) prevented the construction of an accurate geological cross section. The map is based on the integration of the GEODE mapping for the Iberian Range and the Ebro Basin (1:50000 continuous geological map; López- Olmedo et al., 2011; Robador Moreno et al., 2011, respectively) and the 1:1,000,000 mapping of the Iberian Peninsula for the Catalan Coastal Ranges; Rodríguez Fernández et al., 2014). Main structural features are highlighted (dashed lines refer to folds or nonoutcropping faults, whereas solid lines refer to outcropping faults). Datum and projection type for all the maps presented in this work are ETRS89 and UTM (zone $30^{\circ} \mathrm{N}$ ), respectively.

The Middle Triassic sequence is composed by two dolostone levels (M1 and M3 in Figure 3) and an interbedded marly unit containing frequent gypsum layers (M2, Ortí et al., 2018; Figure 3). The latter, together with the Keuper facies, are the main Mesozoic décollements in the study area (M2 mostly to the East and the Keuper units mostly to the West, Figure 3) and promote decoupling between the underlying Paleozoic-Lower Triassic sequences and the overlying Upper Triassic to Cenozoic units.

The Triassic sedimentary sequence is topped by a thin unit consisting of finely laminated dolostones (Imón Formation), overlain by dolomitic breccias and carbonates with evaporites (Cortes de Tajuña Formation) and a homogeneous sequence (up to $1 \mathrm{~km}$ thick) of Jurassic marine limestones, dolostones, and mudstones (San Román \& Aurell, 1992). On top of them, the Lower Cretaceous consists of continental and marine sequences grading from shales, marls, limestones, and sandstones in the base to alternating marls and limestones with abundant lignite to the top (Canérot, 1974; Soria, 1997). Upper Jurassic and Lower Cretaceous units were coeval to the second rifting stage in the Iberian domain (see section 2.1). Although thinner than in the Cameros and southern Maestrazgo Basins, they display important thickness variations in the study area, where three main depocentral areas can be distinguished (see location in Figure 4): the Oliete, Morella, and Perelló subbasins to the west, south, and east, respectively (following Salas \& Guimerà, 1996). Synrift, Upper Jurassic sequences crop largely out in the Perelló and eastern Morella Basins (see Figure 4; García de Domingo et al., 1982a, 1982b), whereas they are partly absent to the west, where thick Lower Cretaceous successions unconformably overlie Lower and Middle Jurassic carbonates (AlmelaSamper et al., 1975).

The onset of postrift sequences is marked by the Albian Utrillas Formation (Liesa et al., 2006; RodríguezLópez et al., 2009), which is made of versicolor continental shales and sandstones (Aguilar et al., 1971) that are overlain by a homogeneous sequence of Upper Cretaceous limestones and dolostones. The latter shows 
an almost constant-thickness, ranging between 100 and 200 m (Martínez-Durán, 1997). Finally, Cenozoic units across the study area crop largely out in the Ebro basin and in different intramountain basins of diverse sizes (Figure 4). The Cenozoic is mainly formed by continental deposits of alluvial origin that range from conglomerates in the basin margins to sandstones, shales, gypsum, and lacustrine limestones toward intermediate and central domains (González, 1989; Muñoz, 1992b; Pérez, 1989). They include a lower sequence, displaying syncline or synclinorium geometries, that is coeval to shortening in the study area (Paleogene-lower Miocene in the Iberian Range and Paleogene in the Catalan Coastal Ranges; Guimerà et al., 1990; Roca \& Guimerà, 1992) and is unconformably overlain by an upper, synextensional, and flatlying Neogene sequence (Figure 3).

\subsection{Structure of the Study Area}

The study area encompasses (i) the northeastern part of the Iberian Range, corresponding to the Eastern North Branch (as defined in de Vicente et al., 2018); (ii) the southernmost outcrops of the Catalan Coastal Ranges; (iii) the transition between both previous domains, the so-called Linking Zone; and (iv) the Ebro Basin in the North. Outcrops in the Eastern North Branch are dominated by Lower-Middle Jurassic sequences as well as by the Lower Cretaceous, synrift units of the Oliete subbasin. They are bounded to the south by the Paleozoic outcrops coring the Montalbán anticline (see location in Figure 4; Casas et al., 1997) and to the north by the Cenozoic units of the Ebro Basin, in the footwall of the Sierra de Arcos thrust system (Figure 4). These units are deformed by NW-SE striking structures that connect and/or are relayed by E-W trending thrust-related folds (Almela-Samper et al., 1975; Ríos-Aragüés et al., 1978). Thrusts show topto-the-north displacements in the North Branch, with a minor right-lateral oblique component (Guimerà et al., 2004).

The Linking Zone is characterized by a stratigraphic sequence that sharply thins to the North, the thick Upper Jurassic-Lower Cretaceous successions of the Morella Basin dominate in the South (Martín et al., 1972) but disappear northward (Figure 4; Marín \& Duval, 1976). This zone of the Iberian Range displays significant structural trend variations (Guimerà, 1983, 1988), varying from E-W to NE-SW and NW-SE, that are controlled by dominantly north verging, fault-related folds (Nebot \& Guimerà, 2016a, 2016b). The southern Catalan Coastal Ranges are mainly formed by NE-SW striking, NW verging folds and thrusts that partly involve the Paleozoic basement and resulted from oblique convergence with a strong left-lateral component (Anadón et al., 1985; Julià \& Santanach, 1984). Paleozoic units are unconformably overlain by Mesozoic sequences consisting of thin Triassic-Lower Jurassic successions to the NW (García de Domingo et al., 1982b) and thick Upper Jurassic-Lower Cretaceous sequences to the SE (Perelló Basin, Orche-García et al., 1978, Figure 4). Contractional structures deforming the Mesozoic are partially overlain by syncontractional to postcontractional Cenozoic sedimentary units and cut by the late extensional features controlling the development of the Tortosa and Móra Basins (see location in Figure 4; Baix Ebre Basin in Roca \& Guimerà, 1992) that host Miocene to Holocene sedimentary infills (Arasa-Tuliesa \& Cabrera-Pérez, 2018).

To the north of the Iberian and Catalan Coastal ranges, the Ebro Basin mostly consists of subhorizontal Cenozoic units, although slightly tilted bedding planes are recognized to the North of the study area (Beltrán Cabrera et al., 1978). These tilted units correlate to two main antiformal structures that are recognized from surface structural data and seismic interpretations (Figure 4): the Puigmoreno and Caspe anticlines (Mediato et al., 2017; Salas et al., 2001).

\section{Workflow and Results}

The aim of the present work is to characterize the subsurface structure in the transition between the Iberian and Catalan Coastal Ranges, specifically focusing on unraveling along-strike changes and basement geometries as well as thick- and thin-skinned tectonics relationships. In this characterization, we had to face one main limitation: Previous subsurface information in the area is scarce (lack of available seismic surveys and very limited well data). To overcome this drawback, we carried out a new gravity survey and density determinations that, combined with surface structural and geological mapping data, were the basis for the construction of seven serial cross sections. From these cross sections, a 3-D model considering the key stratigraphic horizons and the main faults was built and its uncertainties were reduced by the 3-D inversion of gravity data. 


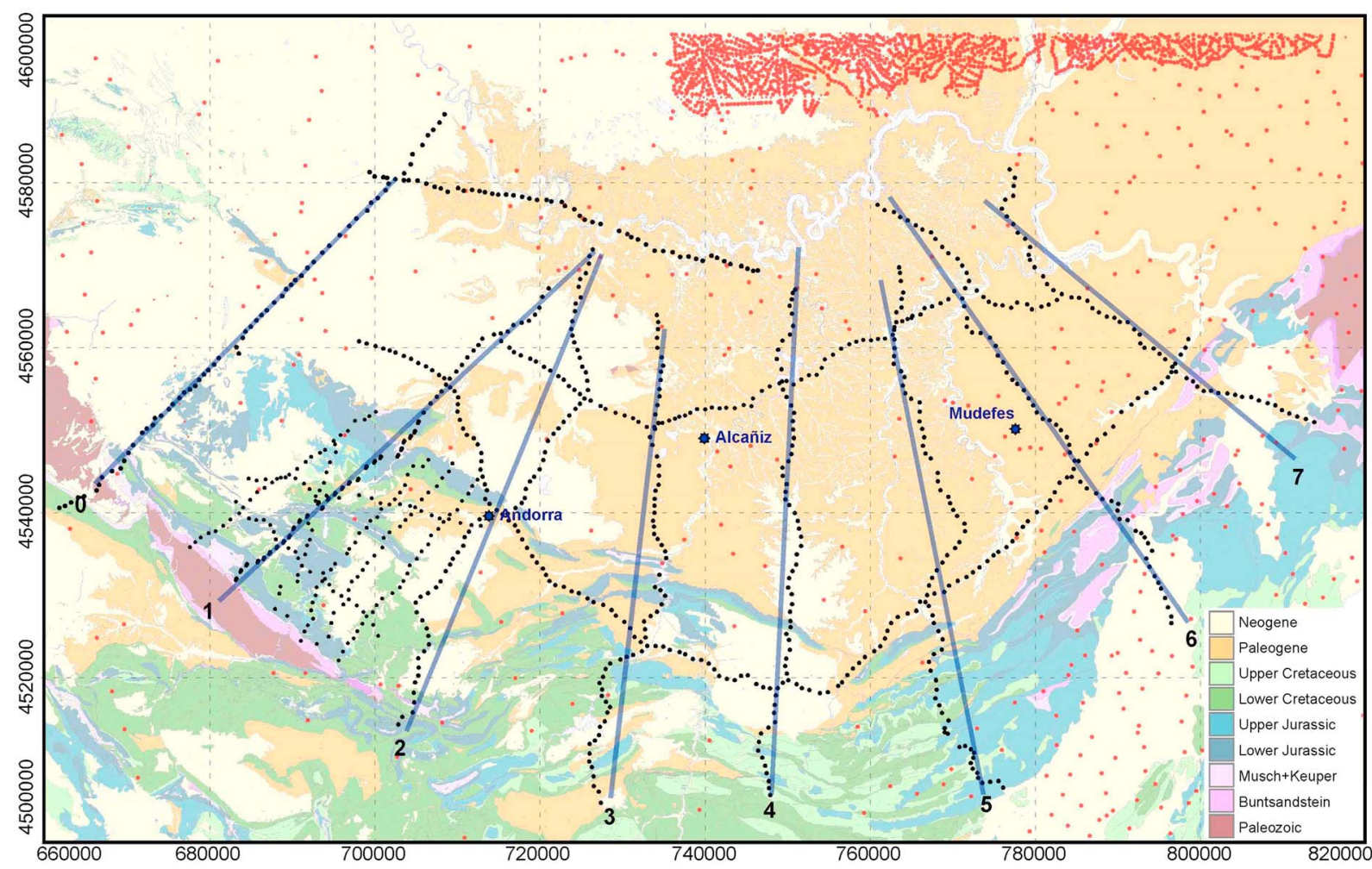

Figure 5. Distribution of the gravity stations used to obtain the Bouguer anomaly. Red: SITOPO database (Ayala et al., 2016); black: points acquired for the present study. Blue dots indicate gravimetric bases used for the gravity survey. Universal Transverse Mercator coordinates (zone 30T-north, ETRS89).

\subsection{Gravity Data}

\subsubsection{Gravity Survey}

The acquisition of gravity data, a magnitude sensitive to lateral density variations in the subsurface, is an experimented, fast, and cost-effective technique that provides important constraints to reconstruct geometries at depth (Goleby et al., 1989). Gravity data considered in this work come from two different sources: 1,953 sites from the SITOPO database (Ayala et al., 2016) and 938 new sites acquired in the frame of this study (Figure 5). The new gravity sites were measured along eight across-strike and three along-strike profiles distributed throughout the four previously described structural domains (see section 2.3). The separation of gravity stations along the profiles was $1 \mathrm{~km}$, whereas the average density of the stations in the whole area is about 1 point every $4 \mathrm{~km}^{2}$.

Gravity data were acquired using two different gravity meters: a Scintrex CG5 (with an accuracy of 0.001 mGal) and a Lacoste \& Romberg (with an accuracy of $0.005 \mathrm{mGal}$ ). Gravity measurements were performed in cycles of a few hours to minimize the instrumental drift. Tidal correction was also applied. Due to the large extension of the study area $\left(11,325 \mathrm{~km}^{2}\right)$, three gravimetric bases were used to tie up the stations (see location in Figure 5): Andorra and Mudefes, established on the field and tied up with the base of Alcañiz, a first-order base that is in turn tied up with the IGSN-71 network. Gravity measurements were repeated in 74 locations (9.6\% of the total stations) with an average root-mean-square (RMS) of $0.02 \mathrm{mGal}$.

Horizontal coordinates $(X, Y)$ and elevation $(Z)$ were measured at gravity sites with two bifrequency differential instruments: a GPS TRIUMPH (from JAVAD), which was used as a base station, and a GPS Promark III (from ASTEH). They have millimetric and centimetric precision, respectively. To ensure the quality of these data, X, Y and Z coordinates of 62 sites (approximately $8 \%$ of the total survey points) were repeated. The average RMS of the repetitions is $0.22 \mathrm{~m}$ for the $X$ coordinate, $0.15 \mathrm{~m}$ for the $Y$ coordinate, and 0.11 $\mathrm{m}$ for the elevation. 

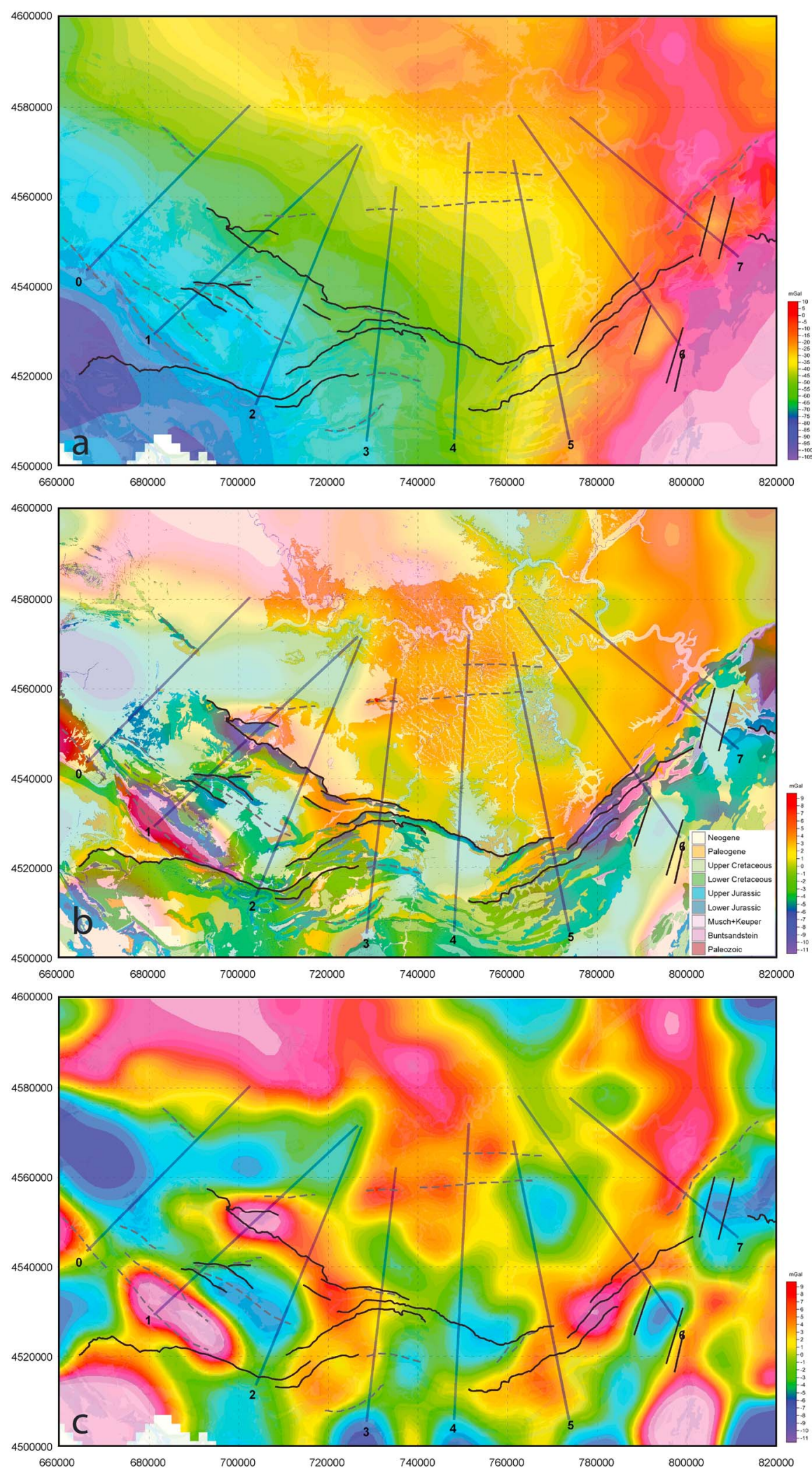

Figure 6. a) Bouguer anomaly map of the study area. b) Geological map of the study area presented as a transparent overlay superposed to the residual Bouguer anomaly map. c) Residual Bouguer anomaly map. Blue lines indicate the location of the modeled profiles. Universal Transverse Mercator coordinates (zone 30T-north, ETRS89). Black lines indicate main thrusts whereas gray dashed lines are the traces of the main folds. 


\subsubsection{Bouguer and Residual Bouguer Anomaly Maps}

In order to interpret the gravity data, we computed the complete Bouguer anomaly (Figure 6a) using the GRS80 geodetic system formulae, with orthometric heights, and density reduction of $2.67 \mathrm{Mg} / \mathrm{m}^{3}$. To obtain the Bouguer anomaly, the following corrections were applied to the gravity measurements: theoretical gravity correction, free-air correction, Bouguer slab correction, and topographic correction. The topographic correction was applied using the Hammer (1939) method. The near topographic correction, up to $50.3 \mathrm{~m}$, was carried out in the field whereas the medium and far topographic correction were carried out using the inhouse CCT software (Plata, 1991) with a 100-m × 100-m Digital Terrain Model (DTM) from the Spanish Army Geographical Survey. To account for the uneven distribution of the gravity measurements, the point data were gridded during calculation of the Bouguer anomaly with a grid spacing of 2,000 $\mathrm{m}$ using the minimum curvature method.

Bouguer anomalies are due to the combined effect of sources at different depths. To investigate gravity anomalies coming from the uppermost crust (residual anomaly related to the basement and sedimentary cover down to $~ 5,000-\mathrm{m}$ depth), it is necessary to remove the contribution of deeper sources (i.e., the regional gravity anomaly) from the Bouguer anomaly. The regional gravity anomaly was assumed to be a third order polynomial surface and subtracted from the Bouguer anomaly in order to obtain the residual Bouguer anomaly map (Figure $6 \mathrm{~b}$ ). The latter anomaly was the one used for the $2.5-\mathrm{D}$ gravity modeling and the $3-\mathrm{D}$ gravity inversion.

The Bouguer anomaly in the study area ranges between -100 and $0 \mathrm{mGal}$ and roughly follows the structural grain of the main units (Figure 6a). Most negative values are aligned with the North Branch of the Iberian Range where anomalies trend approximately NW-SE and there is a positive gradient toward the Ebro foreland basin. On the contrary, the highest values (from -30 to $0 \mathrm{mGal}$ ) were obtained for the Catalan Coastal Ranges, with anomalies that trend NNE-SSW and define a rough positive gradient toward the Mediterranean Sea. Intermediate Bouguer anomaly values (ranging between -80 and $-40 \mathrm{mGal}$ ) are observed in the Linking Zone where anomalies run approximately N-S, almost perpendicular to the main structures. This apparently anomalous direction results from the interference between the NW-SE contour trend at the limit between the Ebro Basin and the Iberian Range, and the NE-SW contour direction when the Iberian Range approaches the Mediterranean Sea. The obtained Bouguer anomaly follows the regional trends defined from wider-scale, lower-resolution previous surveys (Ayala et al., 2016; Seillé et al., 2015) and responds to a crustal distribution characterized by a moderate thickening beneath the Iberian Range (Casas-Sainz \& De Vicente, 2009; Guimerà et al., 2016; Seillé et al., 2015) and a progressive thinning toward the Mediterranean Sea (Roca \& Guimerà, 1992).

The residual Bouguer anomaly (Figures $6 \mathrm{~b}$ and $6 \mathrm{c}$ ) ranges between -10 and $+8 \mathrm{mGal}$ (97\% of the values) although in the SW and SE corners of the study area, the anomalies reach up to +30 and $-25 \mathrm{mGal}$, respectively. Anomalies have a few kilometers wavelength and extend along strike for tens of kilometers. They are NW-SE trending in the North Branch where two gravity highs coinciding with the Montalbán basement anticline to the South and the Sierra de Arcos FTS to the north, are recognized. These anomalies are separated by a gravimetric low and end laterally to the east against a NNE-SSW oriented maximum (along the eastern termination of the Oliete subbasin; Figure 4) that discontinuously extends to the north through the Cenozoic units of the Ebro Basin and partly overlaps with the Puigmoreno and Caspe anticlines (Figure 4). To the east, there is a significant NNE-SSW oriented gravity high superimposed on the Mesozoic units of the Catalan Coastal Ranges and two relative minima that coincide with the Tortosa and Móra Neogene basins (see location in Figure 4). The Priorato anticline, cored by Paleozoic outcrops, is overlapped by a relative gravity high in the north but a gravity low in the south. In the Linking Zone, residual gravity anomalies show a more complex pattern and the occurrence of a relative gravity minimum in the transition between the frontalmost structures of the Iberian Range and the Cenozoic units of the Ebro Basin stands out.

\subsection{Density Determinations}

A thorough knowledge of the physical properties of rocks (density in the case of gravity surveys) helps constraining the modeling because, once the petrophysical properties are accurately defined, the uncertainties in the geometry of the modeled horizons are reduced. With this purpose, 827 samples were collected from nonweathered outcrops across the study area and their density was measured. The samples were chosen to represent the whole range of units cropping out along the studied profiles. Besides, more than 700 


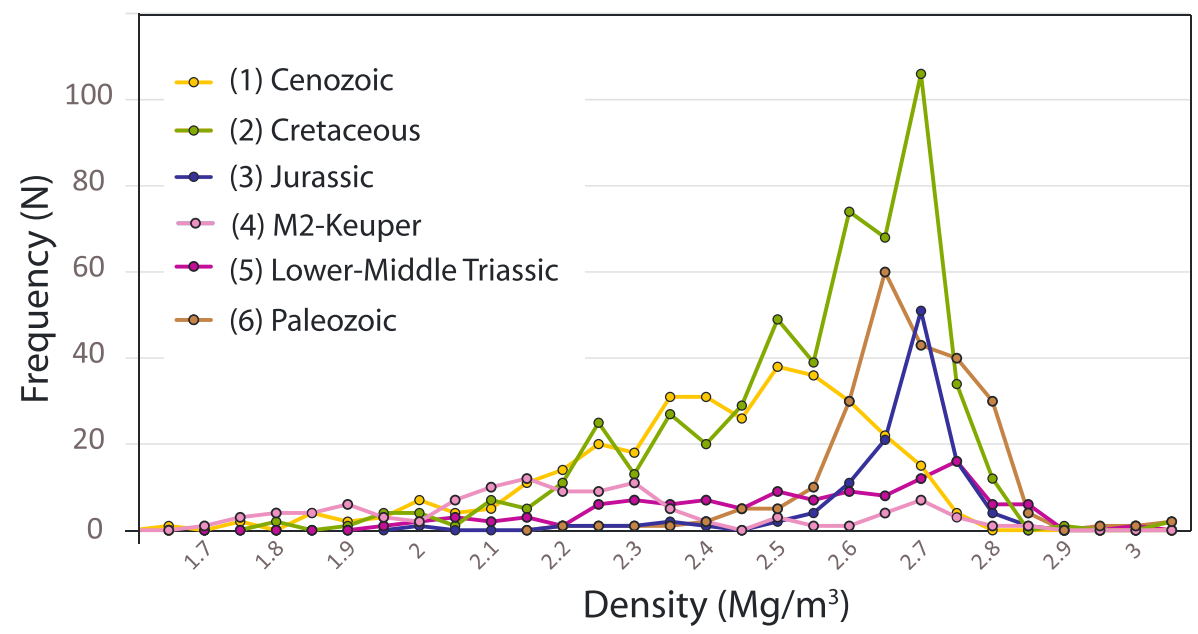

Figure 7. Line chart for the frequency of density values in the six units considered for gravity modeling. Numerical values given in Pueyo et al. (2016).

additional density data from previous studies and wells in the Iberian Range and the Ebro, Tagus, and Almazán basins were also considered (all of them compiled in Pueyo et al., 2016).

Density measurements were performed using the double weighing method in two different sample types: (i) regular cubes weighting between 0.3 and $0.6 \mathrm{~kg}$ that come from outcrop samples of, at least, $2 \mathrm{~kg}$ of rock (García-Lobón et al., 2014; Plata Torres, 2009) and (ii) irregular samples weighting between 10 and $60 \mathrm{~g}$ with an average volume of $12 \mathrm{~cm}^{3}$. Individual sample density values range from $1.28 \mathrm{Mg} / \mathrm{m}^{3}$ (Neogene conglomerates) to $3.5 \mathrm{Mg} / \mathrm{m}^{3}$ (iron-rich Devonian quartzites), and, on the overall, they indicate a progressive increase of the mean density from younger to older rocks with the exception of the Triassic gypsum and shales within the Muschelkalk and Keuper facies (Pueyo et al., 2016). On the basis of our measurements and the previously published density values, we divided the stratigraphic sequence in the modeled sections into six units. Their density corresponds to the average density values in Pueyo et al. (2016), obtained from the data set represented in Figure 7. These units and their average densities are, from the top to the base of the stratigraphic sequence, as follows:

1. The Cenozoic, with an average density of $2.40 \mathrm{Mg} / \mathrm{m}^{3}$. From this unit, we have independently considered the Quaternary in the two easternmost cross sections, where its higher thickness has a relevant effect in the observed gravity data since its average density is very low $\left(1.80 \mathrm{Mg} / \mathrm{m}^{3}\right)$.

2. The Upper and Lower Cretaceous limestones, dolostones, shales, mudstones, and sandstones. They were considered as a single unit with an average density of $2.56 \mathrm{Mg} / \mathrm{m}^{3}$.

3. The Jurassic limestones and mudstones, with an average density of $2.62 \mathrm{Mg} / \mathrm{m}^{3}$.

4. The Middle-Upper Triassic shales and gypsum (Keuper and Muschelkalk-II facies) with the lowest mean density $\left(2.25 \mathrm{Mg} / \mathrm{m}^{3}\right.$ in average).

5. The Lower Triassic sandstones (Buntsandstein) and Middle Triassic dolostones (Muschelkalk), with similar average densities of $2.57 \mathrm{Mg} / \mathrm{m}^{3}$, although some Muschelkalk dolostones have rather high density values $\left(>2.80 \mathrm{Mg} / \mathrm{m}^{3}\right)$.

6. The Paleozoic, with an average density of $2.68 \mathrm{Mg} / \mathrm{m}^{3}$. It is the stratigraphic unit that yields the highest density values. Density measurements in the Paleozoic units do not show any major difference in this property when the basement of the Iberian Range is compared to the Catalan Coastal Ranges (in spite of the previously described lithology changes; see section 2.2). Regular density values in the lithological types cropping out in the east $\left(2.74 \mathrm{Mg} / \mathrm{m}^{3}\right.$ in diorites, $2.65 \mathrm{Mg} / \mathrm{m}^{3}$ in granodiorites, 2.63 $\mathrm{Mg} / \mathrm{m}^{3}$ in granites, $2.66-67 \mathrm{Mg} / \mathrm{m}^{3}$ in porphyry dykes, $2.63 \mathrm{Mg} / \mathrm{m}^{3}$ in quartzites, and $2.68 \mathrm{Mg} / \mathrm{m}^{3}$ in slates; Bott \& Masson-Smith, 1960; Elming, 1980; Hatherton \& Leopard, 1964) closely approximate the average density value we considered that is also similar to the density values used for the basement in previous gravity studies in the Iberian Range $\left(2.7 \mathrm{Mg} / \mathrm{m}^{3}\right.$ in de Vicente et al., 2009 and Guimerà et al., 2016). 


\subsection{Gravity-Constrained Cross Sections and 2.5-D Gravity Modeling} 3.3.1. Cross-Sections Construction: Input Data and Feedback Between Structural Data and Gravity Modeling

Seven balanced cross sections were constructed across the study area (see location in Figure 4): They are distributed along the three deformed domains previously described in section 2.3 (the eastern North Branch of the Iberian Range, the Linking Zone, and the southern Catalan Coastal Ranges) and extend to the north across the slightly deformed to undeformed Ebro basin. Cross sections are perpendicular to the arched strike of the geological structures and run parallel or oblique to the main $\mathrm{N} 010^{\circ} \mathrm{E}$ tectonic transport direction in the study area (de Vicente et al., 2009). They define a radial pattern and converge toward the Ebro Basin, with lengths ranging from 49 to $66 \mathrm{~km}$.

The cross sections are based on surface data (geological mapping, bedding data, and stratigraphic logs) extracted from available geological maps (1:50,000 scale, MAGNA series, Instituto Geológico y Minero de España), as well as additional field data acquired for this work and well information (see location of wells in Figure 4). Boreholes reach different depths, and log information comes from two different data bases: (i) Lanaja's (1987) compilation and (ii) the data set of the Ebro Basin Water Authority (Confederación Hidrográfica del Ebro).

Cross sections were improved through modeling using the residual Bouguer anomaly obtained in the gravimetric sections (roughly parallel to the structural ones). First, an initial cross section was built considering only surface and well data. Then, cross sections were depth constrained through an iterative, feedback process between the geological information and the 2.5-D forward gravity modeling. This feedback ran until the gravimetric response of each cross section fitted the observations. The 2.5-D forward gravity modeling was carried out using the GM-SYS module (implemented in the Oasis Montaj ${ }^{\circledast}$ software by Geosoft), which calculates the gravimetric response of the density models with an algorithm based on Talwani et al. (1959) and Won and Bevis (1987). The different layers of the model are extended far enough to avoid edge effects. The inherent nonuniqueness of the results of the potential field method is constrained by the petrophysical data and the feedback between the modeling and the cross sections. Since the density values are well constrained by several hundreds of laboratory determinations, we kept fixed the densities and modified the depth geometries to adjust the observed gravity anomaly.

The gravity-consistent cross sections were subsequently balanced and restored to the top of the synrift sequence. We considered pin lines located in the northern margin of the cross sections, in the undeformed Ebro basin, and unfolded and unfaulted horizons using Move software (Midland valley). Minor variations in the cross sections were implemented during cross-section balancing, and, as the final stage of feedback between geology and geophysical modeling, we checked that these variations were still compatible with the gravity signal across the studied sections.

After this geology-gravity feedback, the RMS in the sections ranged between 0.33 and 0.83 mGal, less than $5 \%$ of the observed anomalies average amplitude. The final product of this process was the seven balanced, gravity-consistent cross sections that are described in the following sections.

3.3.2. Eastern Part of the North Branch (Cross Sections 1 and 2)

As previously mentioned, the western area is bounded by two main NW-SE striking features, the Montalbán anticline to the south and the Sierra de Arcos thrust system to the north. They have a kilometric wavelength although their width decreases progressively to the east where both structures end laterally up. They are relayed by a NE-SW striking thrust system formed by smaller wavelength (usually lower than $1 \mathrm{~km}$ ) structures that display a curved geometry in map view and deform Jurassic and Cretaceous sequences (the socalled Ejulve threshold or sedimentary high, see location in Figure 4). The Montalbán anticline and Sierra de Arcos thrust correlate to residual positive anomalies that have their maximum values along Cross Section 1 (Figure 8a) but progressively decrease to the east (Cross Section 2, Figure 8b), as the structural relief of the structures does. They end along-strike against a positive anomaly that correlates with the Ejulve high (see location in Figure 4).

The Montalbán anticline is a basement-involved structure extending along strike for about $25 \mathrm{~km}$. Along Cross Section 1, this anticline is a pop-up, characterized by a steeply south dipping to overturned southern limb and an intermediately north dipping northern limb (Casas et al., 1997), the latter affected by high-angle normal and reverse faults (Figure 8a), with no significant decoupling along Triassic Keuper facies. 

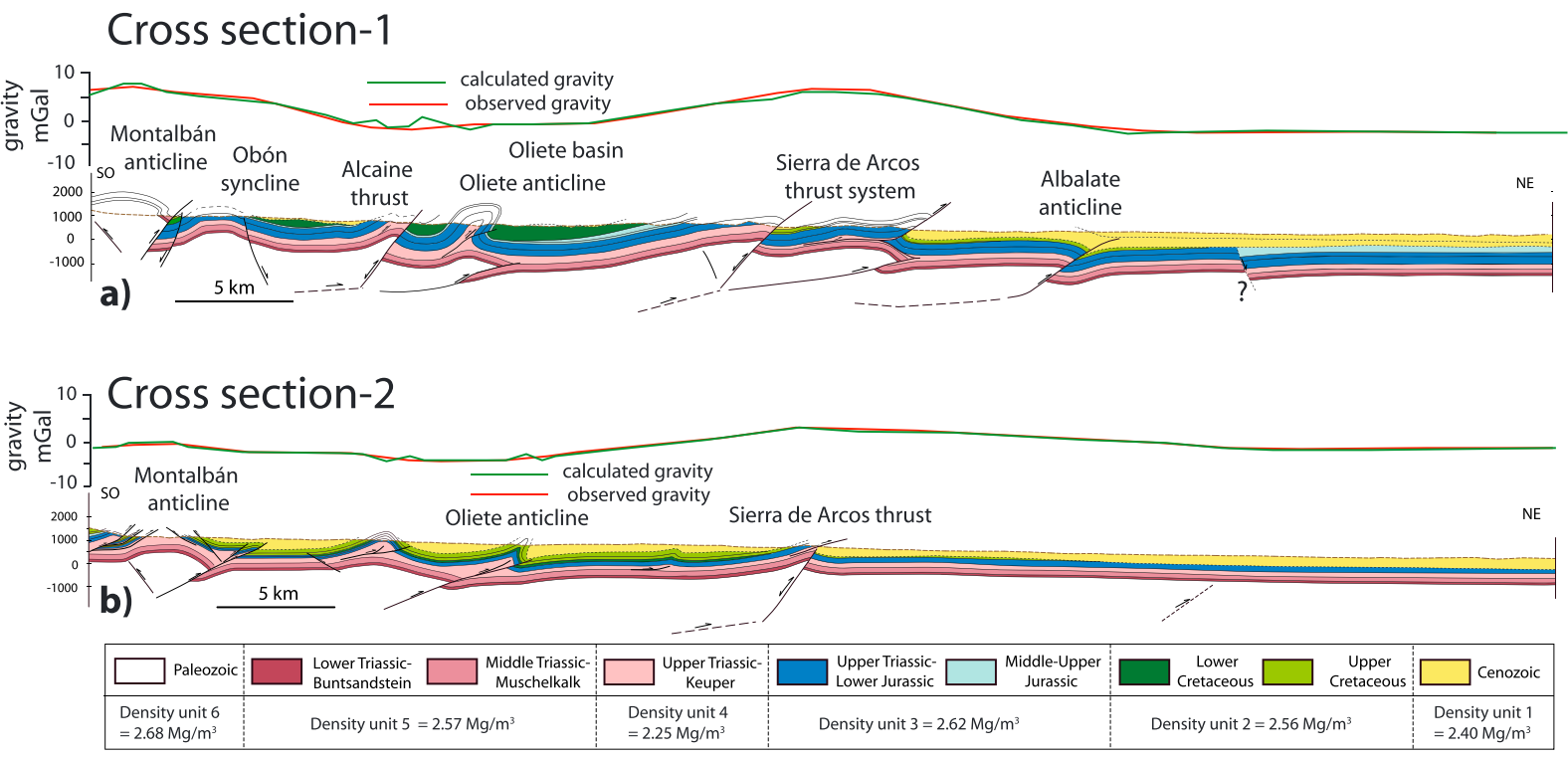

Figure 8. Gravity-consistent, balanced cross sections (a, b) along the Eastern North Branch. The corresponding observed and calculated gravity anomalies are indicated in the upper part.

Conversely, in Cross Section 2, Upper Triassic Keuper units crop largely out and behaved as an effective décollement enhancing the development of thin-skinned, Keuper-detached thrusts both along the northern and southern limbs of the Montalbán anticline (Figure 8b). The whole Triassic sequence is well exposed in this area that, in absence of any other surface or well data, has been considered as a reference for Triassic thicknesses in the North Iberian Branch and the Linking Zone (but not the Ebro Basin, in Cross Sections 1 to 5).

The Sierra de Arcos thrust system consists of two main structures: a southern NW-SE striking thrust and a northern E-W striking thrust that is overlain to the east by the Cenozoic units of the Ebro Basin (Figure 4). Both structures branch to the west and display Mesozoic sequences in their hanging walls that shallowly dip to the south. These Mesozoic sequences include Upper Jurassic to Aptian units in the hanging wall of the southern thrust (maximum preserved thickness of $~ 650 \mathrm{~m}$; Ríos-Aragüés et al., 1978) that are absent in their footwall, pointing out that this structure behaved as a normal, south dipping fault during Late Jurassic and Early Cretaceous times. Subsequent compression during the Cenozoic produced the inversion of the previous extensional fault (Casas et al., 1997), whereas the northern thrust in the Sierra de Arcos system probably formed as a footwall shortcut. Accordingly to field and gravity data, the southern fault can be interpreted as a high-angle, basement-involved thrust (Figure 8), whereas the northern one can be depicted as a fish-tail type structure involving a lower, north directed basement thrust and an upper thrust displaying a main flat along the Keuper units (Figure 8a).

The Montalbán anticline and the Sierra de Arcos thrust system bound a deformed domain characterized by tight, E-W and NW-SE trending anticlines that are 10 to $15 \mathrm{~km}$ long (the Alcaine anticline to the south and Oliete anticline to the north; Figure 4). These anticlines are cored at surface by the Keuper; they are symmetric to north verging and locally relate to north directed thrusts characterized by long flats within Upper Triassic and Lower-Middle Jurassic units. At depth, these anticlines have been correlated to basement thrusts that, to a different extent, are decoupled from the structures detached along the Keuper units (thrust flats or detachment folding). Anticlines are separated by open, wide synclines that host Jurassic and Cretaceous sequences. Among these units, the Lower Cretaceous unconformably overlies the Jurassic succession and shows a progressive thickening toward the south and an eastward thinning (Aurell et al., 2018; Soria, 1997; cf. thickness of the Lower Cretaceous in Cross Sections 1 and 2, Figure 8). The structural domain located between the Montalbán anticline and the Sierra de Arcos thrust system correlates to a negative residual anomaly that is consistent with the thicker Mesozoic and/or Cenozoic units and the locally thickened Keuper units in the core of the anticlines. 

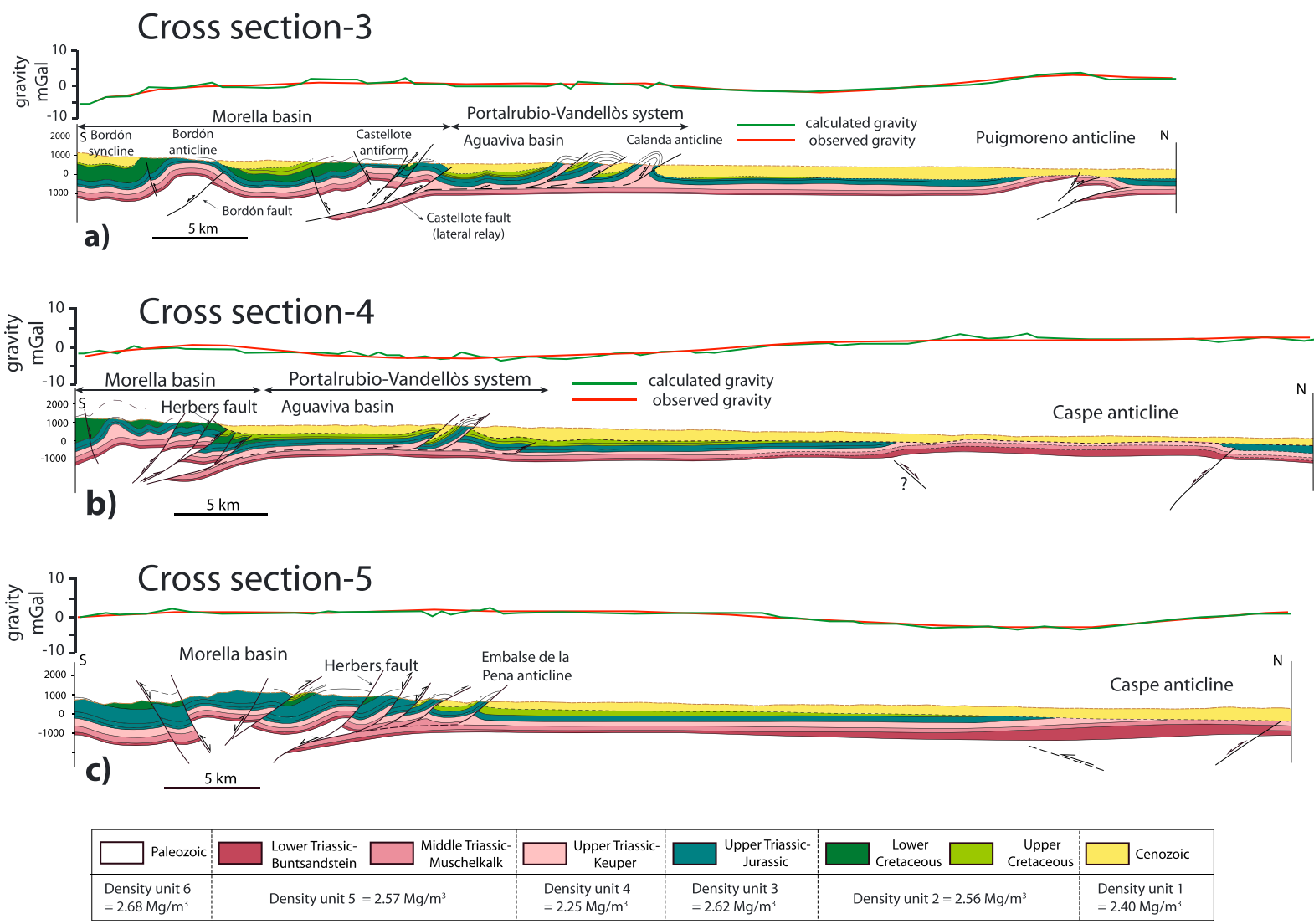

Figure 9. Gravity-consistent, balanced cross sections $(\mathrm{a}-\mathrm{c})$ across the Linking Zone. The corresponding observed and calculated gravity anomalies are indicated in the upper part.

To the north of the Sierra de Arcos thrust system, a main anticline deforming Cenozoic units in the Ebro Basin is recognized (the Albalate del Arzobispo anticline; Figure 8a). It is open and north verging and correlates to a positive residual anomaly that is weaker than those defined for the Sierra de Arcos thrust system and the Montalbán anticline. This anticline is probably related at depth to a north directed, basement thrust that ends up or smooths considerably to the east (cf. Cross Sections 1 and 2 in Figure 8).

3.3.3. Linking Zone (Cross Sections 3-5)

Cross sections in this area (Figure 9) extend through three well-differentiated domains, from south to north: the Morella inverted basin (following Salas \& Guimerà, 1996), the Portalrubio-Vandellòs thrust system, and the southern Ebro Basin. The Morella Basin hosts thick synrift Upper Jurassic and Lower Cretaceous sequences that crop mainly out to the east and west of the surveyed area (Figure 4), respectively, and reach a maximum thickness of $\sim 1,000 \mathrm{~m}$ (Salas et al., 2001; Figure 4). Mesozoic sequences are deformed by a series of high-angle, basement-involved thrusts that are dominantly north directed, although south directed, backthrusts are also recognized (Figure 9c). Their width decreases to the north as the thickness of the sequence they are deforming does.

Thickness variations in the Mesozoic units of the Morella Basin point out that thrusts in this domain frequently correspond to inverted normal faults. Inversion of these faults produced an along-strike changing geometry across the studied profiles. To the west (Cross Section 3, Figure 9a), the Morella inverted basin has been interpreted to consist of two basement anticlines separated by a central syncline; they three sharing a similar wavelength. Anticlines developed in the hanging wall of two inherited normal faults, the Castellote and Bordón faults to the north and south, respectively (following Nebot \& Guimerà, 2016a, 2016b ). The southern fault is NE-SW striking and SE dipping and displays a thickened (up to 1,100 m, Nebot \& Guimerà, 2016a, 2016b) Barremian-Aptian sequence in its hanging wall. Across the studied section (Figure 9a), this fault is covered by Cenozoic, syncontractional to postcontractional units, and its inversion lead to the development of a hanging wall anticline, which is cored at surface by Upper Jurassic units. The 
thickness of the Jurassic sequence across this fold is uncertain (only the Upper Jurassic crops out) and was extrapolated from the Jurassic outcrops located along the lateral continuation of the structure, about $20 \mathrm{~km}$ to the West (Figure 4). To the north, the Castellote fault zone is E-W striking and it is also related to a Jurassic-cored antiformal structure. This antiform is flanked by a south directed back thrust in its southern limb and north directed (partly or totally) inverted normal faults and shortcuts in its northern limb. The whole system (the Bordon and Castellote anticlines and the syncline in between) correlates to a relative, positive residual gravity anomaly (Figures $6 \mathrm{~b}$ and $9 \mathrm{a}$ ), whereas a gravity low was defined in the southern part of Cross Section 3 (Bordon syncline, see location in Figure 4). These anomalies are in agreement with the basement being involved in the structure, in a relatively higher position to the north than to the south.

Across the eastern cross sections (Cross Sections 4 and 5, Figures 9b and 9c), the Morella inverted basin has been depicted as a fault-related, asymmetric antiform involving the basement. Thrusts are dominantly north directed, and Mesozoic units are affected by gentle, thrust-related folds although some smaller wavelength structures could result from detachment folding along Triassic evaporites (see Cross Section 4, Figure 9b; as interpreted further south from seismic lines in Nebot \& Guimerà, 2016a). Upper Jurassic-Lower Cretaceous units thicken southward with the Herbers fault (Figures 4, 9b, and 9c), which laterally connects to the Castellote fault zone, representing one of the main inherited, extensional structures. As in the western sector, the Morella inverted basin across Cross Sections 4 and 5 roughly correlates to relative positive residual gravity anomalies.

To the north of the Morella inverted basin, Lower Cretaceous (pre-Utrillas Formation) units are absent or display thicknesses below $20 \mathrm{~m}$ and Albian sandstones unconformably overlie Jurassic units. This thinner stratigraphic sequence is deformed by the thin-skin Portalrubio-Vandellòs thrust system (Canérot, 1974; Guimerà, 1988) that is separated from the Morella sector by the Aguaviva Cenozoic basin (González, 1989). This thrust system is north directed and involves three main thrust slices that change laterally and whose wavelenght ranges between 1 and $2 \mathrm{~km}$. Thrusts are likely detached along the Keuper to the west (Cross Sections 3 and 4) but along the Muschelkalk (M2) to the east (Cross Section 5), displaying an arcuate geometry in the first domain and sharply changing strike in the second one (Figure 4). They are mostly related to hanging-wall, fault-bend anticlines although, at the frontal thrust of this system, they cut-across the core or the northern limb of previously developed detachment anticlines (Calanda and Embalse de Pena anticlines; Figure 9). In this area, the residual gravity map (Figure 6b) is characterized by a negative anomaly corresponding to the Aguaviva Basin, whereas the Portalrubio-Vandellòs thrust system coincides with residual gravity values that progressively increase from west to east, the strike of the isolines running almost perpendicularly to the structural trend of the thrust system.

In the Ebro basin, Paleozoic to Cenozoic units remain almost undeformed except for the Puigmoreno and Caspe low-amplitude anticlines, located in the northern boundary of the studied profiles, 20 to $30 \mathrm{~km}$ to the north of the frontalmost structure in the Portalrubio-Vandellòs thrust system (Figure 4). The Puigmoreno anticline is recognized at surface by small outcrops of Paleozoic rocks (Carboniferous in age) that are unconformably overlain by Paleogene sequences describing an asymmetric, north verging anticline. This structure correlates to a positive E-W trending gravity anomaly (with an amplitude of $4 \mathrm{mGal}$ ) that closes laterally both to the east and to the west. The Caspe structure is interpreted as a symmetric pop-up in which syncompressional Cenozoic units are shallowly dipping both to the south and to the north and overlie underlying Triassic sequences. A more detailed, seismic-based picture of this structure was proposed by Mediato et al. (2017) who enhanced the role of basement features. The Caspe structure yields a positive residual gravity anomaly (of 2 -mGal amplitude) that required a thickening of Triassic units underneath the Cenozoic (with regard to our reference thicknesses in the Montalbán anticline) to be properly modeled. This thickening is in agreement with well data in the area (see location of wells in Figure 4) and could suggest an initial Triassic age of the faults controlling the Caspe structure.

\subsubsection{Southern Part of the Catalan Coastal Ranges}

Cross sections in this area (Figure 10) extend through four different structural domains: the Perelló inverted basin to the south, the lateral, eastward continuation of the Portalrubio-Vandellòs thrust system, the southward continuation of the basement-involved Priorato structure to the east and the Ebro basin to the north.

The Perelló inverted basin is dominated by Upper Jurassic units and its structure is very similar to that of the Morella Basin: It is bounded and internally deformed by high-angle basement faults inherited from 

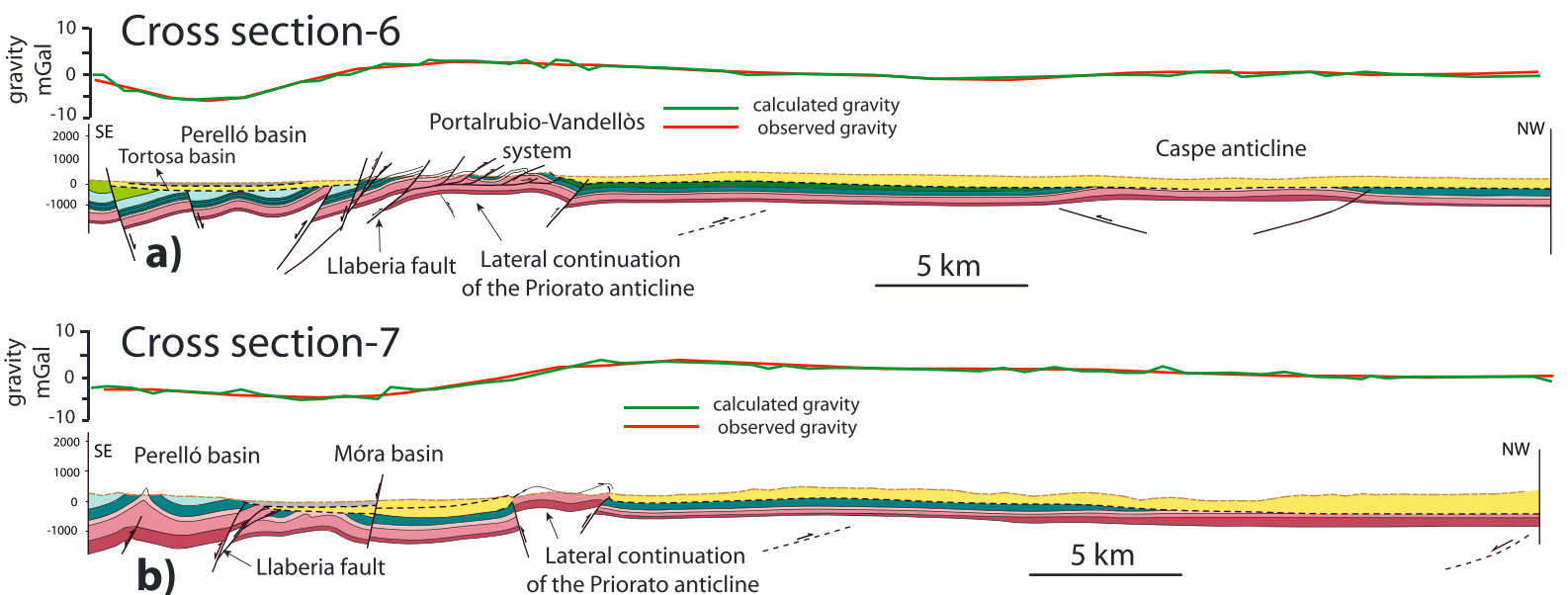

\begin{tabular}{|c|c|c|c|c|c|c|c|c|}
\hline ] Paleozoic! & ]$_{\text {Buntsandstein }}^{\text {Lower Triassic- }} \square \quad \begin{array}{c}\text { Middle Triassic- } \\
\text { Muschelkalk }\end{array}$ & $\square \square_{\text {Trias - M2-Keuper }}^{\text {Mid-Uper }}$ & $\begin{array}{l}\text { Upper Triassic-Lower/ } \\
\text { Middle Jurassic }\end{array}$ & $\square$ Jurassic & $\mathrm{I}_{\text {Cretaceous }}^{\text {Lower }}$ & $\checkmark \begin{array}{c}\text { Upper } \\
\text { Cretaceous }\end{array}$ & Cenozoic & Quaternary \\
\hline $\begin{array}{l}\text { Density unit } 6 \\
=2.68 \mathrm{Mg} / \mathrm{m}^{3}\end{array}$ & Density unit $5=2.57 \mathrm{Mg} / \mathrm{m}^{3}$ & $\begin{array}{l}\text { Density unit } 4 \\
=2.25 \mathrm{Mg} / \mathrm{m}^{3}\end{array}$ & $\begin{array}{l}\text { Density unit } 3 \\
=2.62 \mathrm{Mg} / \mathrm{m}^{3}\end{array}$ & & Density unit $2=2$ & $\mathrm{Mg} / \mathrm{m}^{3}$ & $\begin{array}{l}\text { Density unit } 1 \\
=2.40 \mathrm{Mg} / \mathrm{m}^{3}\end{array}$ & $\begin{aligned} & \text { Density } \\
= & 1.80 \mathrm{Mg} / \mathrm{m}^{3}\end{aligned}$ \\
\hline
\end{tabular}

Figure 10. Gravity-consistent cross sections (a, b) across the Linking Zone. The corresponding observed and calculated gravity anomalies are indicated in the upper part.

Mesozoic rifting stages. Mesozoic units within the basin are gently folded except for a tight anticline appearing in Cross Section 7 (Figure 10b) that is cored at surface by the Keuper units. Thrust sheets strike NE-SW and are dominantly north directed although north dipping and partly inverted basement faults crop out toward the southern part of Cross Section 6 (Figure 10a). Faults controlled the deposition of thicker (up to $1,000 \mathrm{~m}$ ) Late Jurassic-Early Cretaceous sequences to the south of the Llabería fault that represented the northern basin boundary (Salas et al., 2001). These faults probably reactivated previous Triassic-Late Jurassic extensional faults (Juez-Larré \& Andriessen, 2002 and references therein): In Cross Section 7, the modeling of the residual gravity anomaly required a deepening of the Paleozoic basement in the hanging wall of the Llabería fault that was resolved through the thickening of the overlying Triassic units.

To the north of the Llabería fault, the Mesozoic succession thins and the Albian sequence unconformably overlies Lower-Middle Jurassic units. They are affected by the eastward continuation of the PortalrubioVandellòs thrust system that in this domain consists of north directed, NE-SW striking thrusts detached along the Muschelkalk décollement (M2). They are related to hanging-wall fault-bend folds and frequently display curved geometries, along-strike terminations and lateral relays. In Cross Section 6 (Figure 10a), the Portalrubio-Vandellòs thrust system is folded by an underlying basement structure that correlates to a strong NE-SW striking gravity high (recognized in the two surveyed profiles) and probably connects laterally to the Priorato structure (see location in Figure 4). The latter has been described as a basement antiform bounded by high-angle faults that accommodated a reverse left-lateral movement (Teixell, 1988). Regarding the dipslip component, the fault that bounds the basement structure to the north shows a vertical offset of approximately 800 m (Anadón Monzón et al., 1979; Gómez \& Guimerà, 1999) and probably corresponds to an EarlyMiddle Triassic fault that was subsequently inverted during the Cenozoic compression (Gómez \& Guimerà, 1999). To the south, this basement antiform is bounded by the Cenozoic units of the Móra basin. This basin was formed during contractional stages and shows a syncline geometry (Teixell, 1988).

To the north of the sections, the Ebro basin remains almost undeformed except for (i) an interpreted northwestward regional tilting in the area closest to the Catalan Coastal Ranges and (ii) a northern basement structure that laterally connects to the Caspe antiform (in Cross Section 6, Figure 10a). The latter correlates to a wide, weak positive gravity anomaly whose geometry fits with the anomaly calculated for the open, kilometer-wavelength basement antiform depicted in Cross Section 6. This structure can be recognized at surface through a series of shallow tilts in the Miocene units. Both the anomaly and the tilting of Cenozoic sediments end laterally to the East (profile 7, Figure 10b), where the fitting of gravity data was attained by a progressive northward thickening of Cenozoic and Lower Triassic units. The northward 


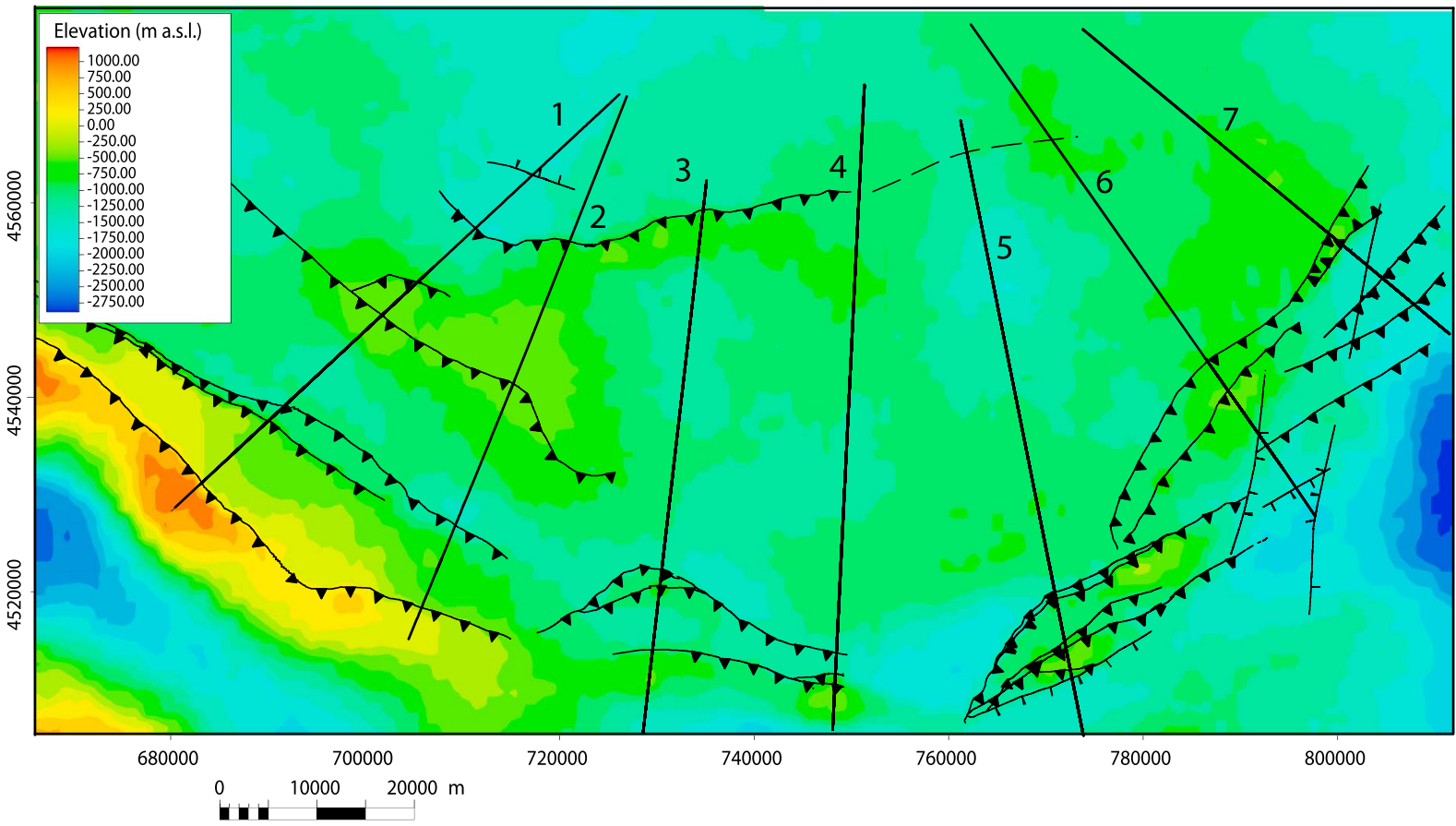

Figure 11. Contours (isohypses) for the surface representing the top of the Paleozoic. Color scale represents elevation above the sea level (meters above sea level, $\mathrm{m}$ a.s.l.). The main faults affecting this surface are shown. The area represented in this map is slightly smaller than the area covered by the geological map in Figure 4.

thickening of the Triassic would be in agreement with the presence of extensional, inherited faults to the north (as interpreted in the northern limb of the Caspe structure; Figures 9b, 9c, and 10a) that were not inverted across this profile.

The whole contractional building in the Catalan Coastal Ranges is overprinted by Neogene-Quaternary extensional features responsible for the development of two NNE-SSW striking basins (the Móra and Tortosa Basins; Arasa-Tuliesa and Cabrera, 2108). These basins are bounded by high-angle normal faults and filled by 100 to $300 \mathrm{~m}$ of low-density deposits that yield to strong negative gravity anomalies (with amplitude of $\approx 5$ to $6 \mathrm{mGal}$ ) aligned with the basins.

\subsection{Three-Dimensional Stochastic Gravimetric Inversion: The Top of the Basement as a Key Surface From the 3-D Model}

After completion of 2.5-D modeling, the remaining unknowns regarding the lateral extension of the main structures and the relationship among them were solved by building up a 3-D model based on the balanced, gravity-consistent cross sections and the surface geology (Figure 4) as well as by performing 3-D gravimetric stochastic inversion using the entire gravimetric network (Figure 5). The stochastic inversion was carried out using GeoModeller software (Calcagno et al., 2008; Guillen et al., 2004) that solves the equations of the inverse problem by finding a set of models that minimize the RMS of the data misfit (observed minus calculated gravity anomalies).

The model covers an area of $160 \times 100 \mathrm{~km}$ and extends to a depth of $5 \mathrm{~km}$. We used the same units and density values as in the 2.5-D modeling that are detailed enough to obtain a model representing the relevant geological sequences and being simple enough to ensure the convergence of the inversion. The final chosen model is the one showing the minimum possible uncertainty (RMS of $1.2 \mathrm{mGal}$ ). From it, we have focused on one key surface (the top of the Paleozoic, Figure 11) that is key to understand basement geometries and their relationship to cover-detached structures.

From the 2.5-D modeling, a good agreement between positive residual gravity anomalies and basement antiforms was established. Similar correlations have been defined in adjacent areas of the Iberian Range (de 
Vicente et al., 2009), although an exception to this general relationship is found in the southern part of the Priorato anticline (Figures $6 \mathrm{~b}$ and $6 \mathrm{c}$ ) that correlates to a residual gravity low. This gravity low (i) can be an effect of the sparse location of the gravity stations in this area (Figure 5) that limits the resolution of the anomalies or (ii) could result from the presence of granites (ICGC, 2006), characterized by density values that are lower than those of the surrounding contact metamorphic rocks (Vigneresse, 1990).

Basement structures (and related gravity anomalies) show a kilometric wavelength and are relatively well constrained if the average density of the gravity stations used for the 3-D inversion is considered (Figure 5). The top of the basement (Figure 11) is characterized by a southern domain where structures have well-defined orientations: They strike NW-SE in the eastern north branch of the Iberian Range and NE-SW to NNE-SSW in the southern Catalan Coastal Ranges (i.e., parallel to the structural trends of the modeled surface), whereas a curved pattern can be inferred across the Morella inverted basin. To the north, the distribution of basement structures becomes more complex, probably due to the interference between NW-SE (Iberian) and NE-SW (Catalan Coastal Ranges) trending structures. As a result, basement features (northern thrust of the Sierra de Arcos thrust system, Puigmoreno, and Caspe anticlines) are shorter along-strike and relay laterally. They are approximately E-W trending and define a basement uplift (Cross Sections 1 to 4 ) that disappears to the East (Cross Section 5, Figure 11). Further to the east (Cross Section 7), the top of the basement also describes an uplifted area in the footwall of the frontal thrust in the Catalan Coastal Ranges. This basement uplift extends to the SW (Cross Sections 6, 5, and 4), defining a wide basement antiform that partly underlies the purely thin-skinned tectonics Portalrubio-Vandellòs thrust system, the basement structural trend being oblique to the Triassic-detached thrusts.

\section{Discussion}

\subsection{Distribution of Basement-Involved and Cover-Detached Structures. Implications in Restored Geometries}

Cross sections across the study area reveal a contribution of both basement-involved deformation and thinskinned folds and thrusts detached along the Middle and Upper Triassic evaporitic décollements. Their relative contribution and distribution changes along-strike of the FTS (Figure 12).

In the eastern North Branch, we interpreted a prevalence of north directed basement-involved thrusts. Basement thrusts in the southern domain of Cross Sections 1 and 2 (Alcaine thrust in Cross Section 1 and Sierra de Arcos thrust in Cross Sections 1 and 2; Figure 8) resulted from the inversion of Early Cretaceous extensional faults (Figures 12 and 13a). They display synrift and prerift sequences in their hanging walls that define shallow to moderately south dipping bedding panels, extending across strike for several kilometers to become subhorizontal away from the inverted normal faults (Figure 8). From bedding orientation in the hanging wall of the Sierra de Arcos and the Alcaine thrusts (Figure 8a), thrust flats at a depth of about 2 $\mathrm{km}$ from the top of the Paleozoic basement are inferred. Whether these thrust flats reactivate or cut a previous extensional detachment is uncertain (no clear synextensional growth geometries can be identified in their hanging walls and this prevents the characterization of extensional fault geometries at depth; Figure 13a). They outline an imbricate thrust system soled by a décollement in the shallow basement (Figure 8a, basement-involved thin-skinned tectonics, Pfiffner, 2006) that resembles the structural style in the eastern Central System, to the west of the study area (Figure 2; De Vicente et al., 2018). Thickness variations in relation to the Sierra de Arcos thrust (named as Sierra de Arcos Fault in Figure 13a) are in agreement with its role as the northern boundary of the Oliete subbasin (Casas et al., 1997; Soria, 1997) that (i) thinned progressively toward the east (cf. the thickness of the Lower Cretaceous units in Cross Sections 1 and 2 , Figure 8), (ii) was probably compartmentalized by the Alcaine and Oliete faults, and (iii) was limited to the south by a series of steeply dipping faults along the southern margin of the Obon syncline (see location in Figure 8a). To the south of these structures, the area where the Montalbán anticline subsequently developed has been depicted as an inherited basement high (Figure 13a).

To the north of the Oliete subbasin domain, the northern Sierra de Arcos thrust is related to a well-developed hanging wall fault-bend anticline (Figure 8a). It is north verging and shows a shallowly south dipping $\left(\sim 15^{\circ}\right)$ back limb that is consistent with a low angle thrust ramp probably corresponding to a shortcut in the footwall of the Sierra de Arcos inverted normal fault to which it branches (Figure 4). Basement structures in the eastern North Branch interacted partly with the main décollement in the cover units: Upper Triassic units 


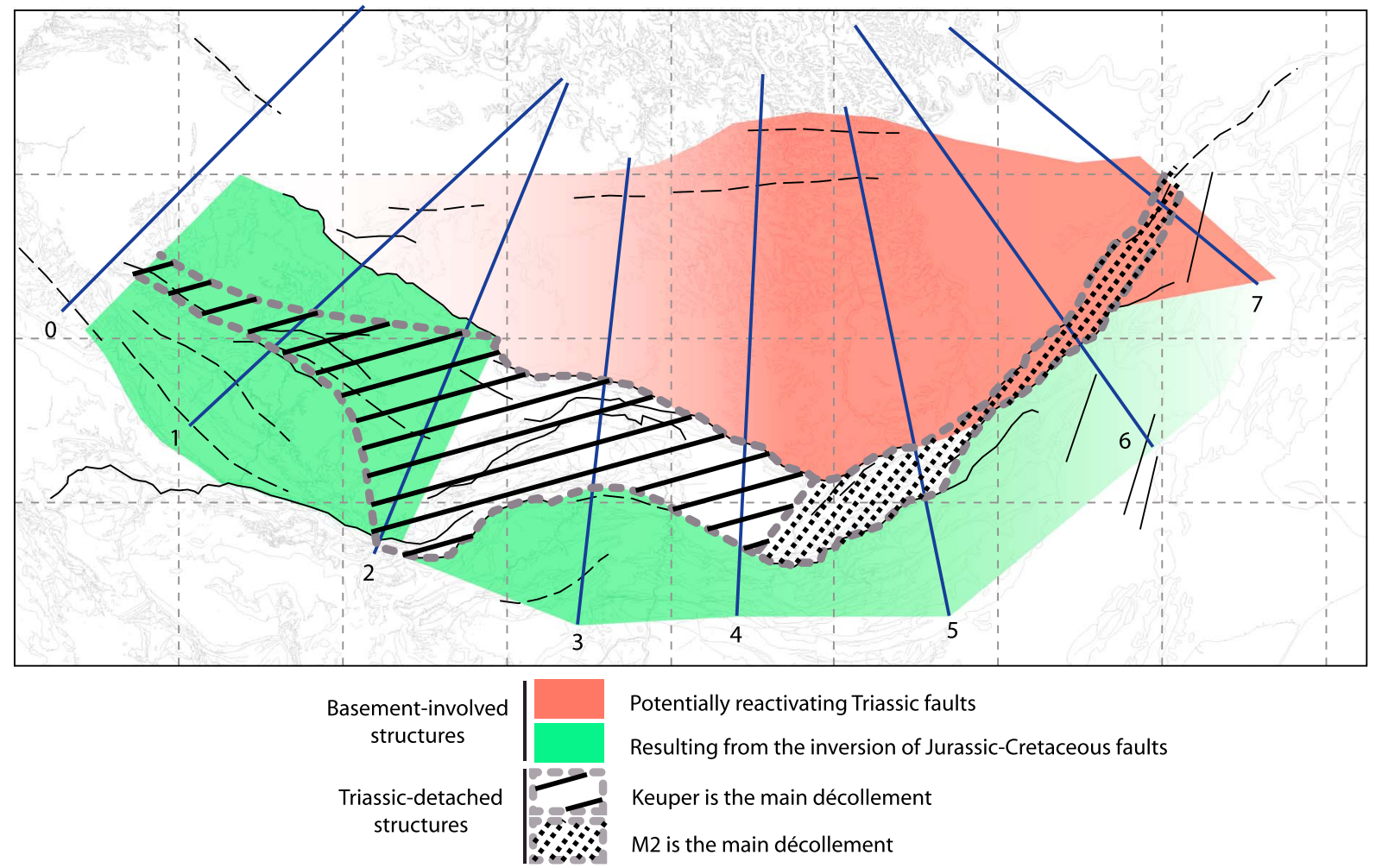

Figure 12. Distribution of basement-involved and cover-detached structures in the study area.

are found in the hinge of the Oliete anticline and are related to thrust flats in the southern and northern limbs of the Montalbán anticline and the northern Sierra de Arcos thrust. These thin-skinned style structures are more abundant to the east (cf. Cross Sections 1 and 2, Figure 8) and are intimately related to underlying basement-involved structures.

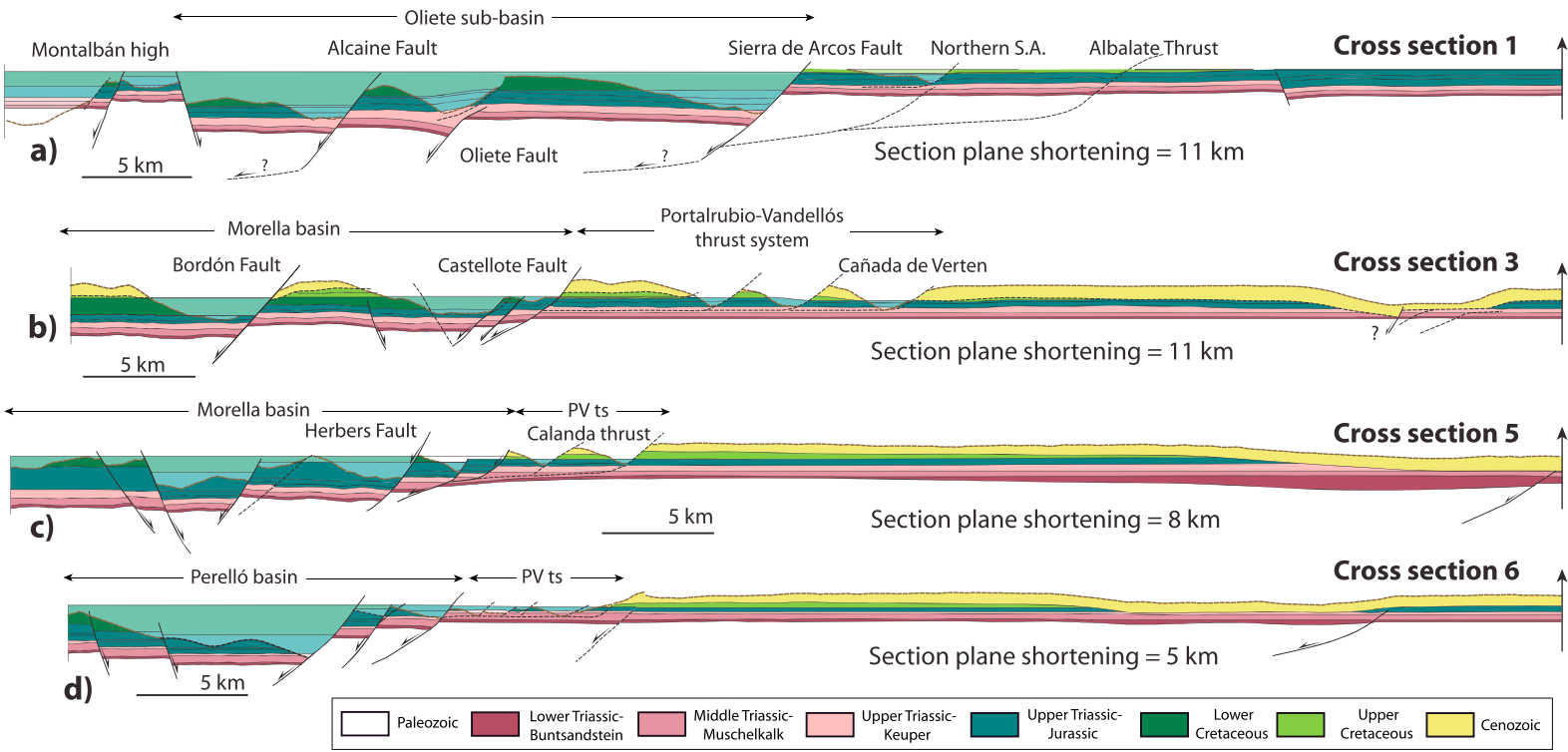

Figure 13. Restored cross sections (a-d correspond to Cross Sections $1,3,5$, and 6 , respectively). S.A. $=$ Sierra de Arcos. PV ts $=$ Portalrubio-Vandellós thrust system. 
Contractional geometries change across the Linking Zone, where a clear areal distinction can be established between (i) a southern domain where basement-involved structures are dominant and (ii) a northern thin-skinned tectonics FTS detached in Triassic evaporite-rich units (Figures 9, 12, 13b, and 13c). The southern domain is confined to the area where the Late Jurassic-Early Cretaceous Morella Basin developed. In this area, shortening was strongly localized along the northern basin border (represented by the Castellote-Herbers faults; Figures $9,13 \mathrm{~b}$, and $13 \mathrm{c})$ but fault inversion $(<1 \mathrm{~km}$ in Cross Section 3, between 1 and $1.2 \mathrm{~km}$ in Cross Section 5, Figure 13) took also place in its central part (the Bordón anticline and the central Morella Basin). The basin boundary probably consisted on an ensemble of normal, closely spaced basement faults that could locally develop flats along the Triassic evaporites (Figure 13c). They are dominantly south dipping and bound a main depocentral area found to the south (Nebot \& Guimerà, 2016a, 2016b). When the restored geometries in the Linking Zone (Figures 13b and 13c) are compared to those across the eastern North Branch of the Iberian Range (see Cross Section 1, Figure 13a), they emphasize a wider extension of the normal faulting domain along the northern basin boundary (more distributed extensional deformation) that resulted in more complex inversion geometries during the Cenozoic. To the south of the study area, seismic-based cross sections (Nebot \& Guimerà, 2016a, 2016b) evidence that the Middle Triassic evaporites (M2 in Figure 3) behaved as an effective décollement during the Cenozoic compression. They enhanced a considerable decoupling between the basement and the cover, the basement being faulted and the cover being folded and thrusted adapting to basement structures (Nebot \& Guimerà, 2016b).

Basement faulting along the Morella Basin boundary transferred shortening to the thin-skinned folds and thrusts to the North (Portalrubio-Vandellós thrust system), the distance between the frontalmost basement-involved thrust and the frontalmost cover-detached thrust sharply decreasing in the eastern section (Cross Section 5, Figure 12). This FTS is detached along Triassic evaporite-rich units, located to the north of the Late Jurassic-Early Cretaceous basin domain, which were not affected by extensional tectonics and therefore formed a continuous subhorizontal level during Mesozoic times (Figures 13b and 13c). These evaporites did not behave as an effective décollement to the north of the frontalmost structure in the Portalrubio-Vandellós thrust system. However, the frontal basement-involved Puigmoreno and Caspe anticlines were formed in this area.

In the southern Catalan Coastal Ranges, basement-involved structures dominate, although they partly overlap with the eastward continuation of the thin-skinned tectonics Portalrubio-Vandellós thrust system (Figure 12). Assuming a mean and prevailing $\sim \mathrm{N} 010^{\circ} \mathrm{E}$ shortening direction during Cenozoic times (De Vicente, 2018; de Vicente et al., 2009), basement structures in this domain strike at an angle of $30-35^{\circ}$ to this mean shortening direction. This strong obliquity (which is not found either in the Eastern North Branch of the Iberian Range or in the Linking Zone) derives from the inherited Cretaceous configuration (Late Jurassic-Early Cretaceous extensional faults strike NE-SW; Salas et al., 2001) but also probably from the Early Mesozoic rifting (Early Triassic in age, Gómez \& Guimerà, 1999; Figure 3). In this scenario, coverdetached thrusting developed (as in the Linking Zone) to the north of the Late Jurassic-Early Cretaceous basin domain and is probably affected by the subsequent inversion of underlying basement faults inherited from Triassic times (Figure 13d). These basement-involved and cover-detached domains are vertically superposed, conversely to the scenario defined for the Linking Zone (Figure 12).

\subsection{Control of Structural Inheritance and Décollement Distribution in the Contractional Geometries Across the Study Area}

From the description above, it is derived that the distribution and geometry of basement-involved and Triassic-detached structures in the study area are controlled by the interplay between three main factors (Figure 14): (1) the obliquity between inherited structures and shortening direction, (2) the continuity of the units hosting the main décollements, and (3) the effectiveness of these décollements.

The obliquity between basement inherited structures and the shortening direction is a first-order factor defining the geometry of contractional FTSs. In the study area, obliquity is strong $\left(30-35^{\circ}\right)$ in the Catalan Coastal Ranges and weak or null in the Eastern North Branch of the Iberian Range $\left(70^{\circ}\right)$ and the Linking Zone (ranging from $60^{\circ}$ to $90^{\circ}$ ). For a strong obliquity, approaching the case of the Catalan Coastal Ranges, FTSs are usually narrow and steep, formed by closely spaced faults that accommodate strong strain partitioning (McClay et al., 2004). On the contrary, when the obliquity is moderate or null, FTSs are 


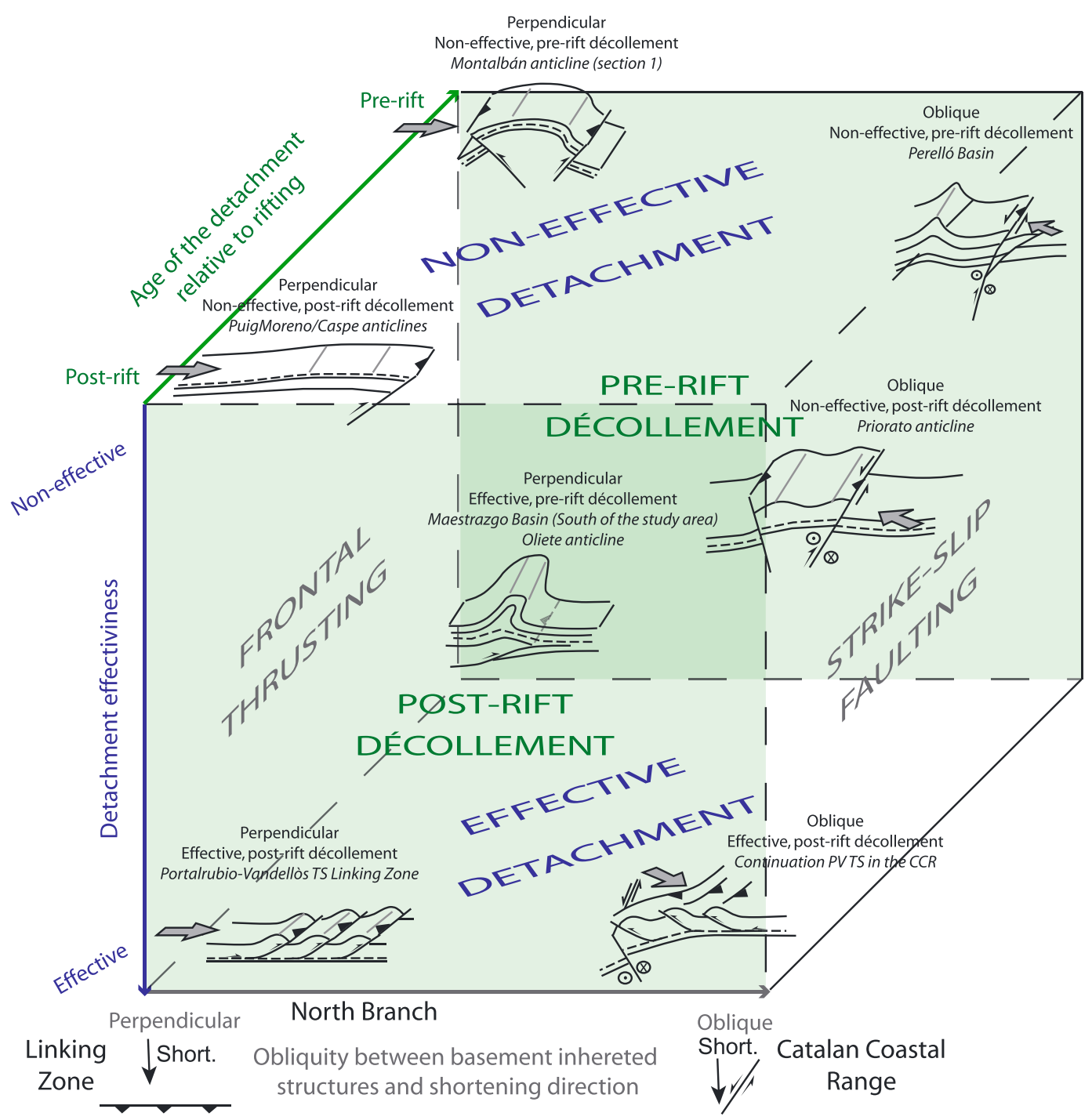

Figure 14. Interplay between the different factors controlling the distribution of basement-involved and cover-detached structures in the study area. PV TS: Portalrubio-Vandellòs thrust system. CCR: Catalan Coastal Ranges. Short: Main shortening direction.

characterized by wider thrust wedges. Thrusts trend parallel to the inherited faults and display only subordinate oblique-slip motion (Casas et al., 2001; McClay et al., 2004). In this scenario, when dealing with basement features, we could expect their reactivation or formation farther into the foreland where the obliquity to the convergence direction is lower, allowing for the development of wider thrust systems. This relationship is consistent with our interpretation in the study area: the frontalmost basement feature in the Ebro basin is at a higher distance from the thrust front in the Linking Zone, whereas lower distances are observed in the Eastern North Branch of the Iberian Range and the Catalan Coastal Ranges (cf. Cross Sections 1, 4, and 7 in Figures 8-10).

Oblique convergence probably exerted a strong control on the width and geometry of the basement-involved deformation domains in the study area and therefore on their interaction with cover structures. Coverdetached folding and thrusting is mostly controlled by the distribution and geometry of décollements at the time when contractional deformation began and by their effectiveness. The first parameter largely depends on the age of the main décollements with regard to the age of the main rifting stage. Riftinginherited structures are mainly Late Jurassic to Early Cretaceous in the Linking Zone and the Eastern North Branch and therefore postdate deposition of the main Upper Triassic décollement that belongs to 
the prerift sequence. In the area where extensional features and the décollement overlap, synextensional deformation produced its early disruption and fragmentation due to two main reasons: (1) the activity of basement faults cutting through the décollement and (2) the early movement of the evaporites from depocentral areas to basin boundaries that could give rise to local welding beneath the extensional syncline axis. Early salt-movement has been recognized in seismic profiles in the nearby Maestrazgo Basin (Nebot \& Guimerà, 2016b) and described in other Iberian extensional basins involving prerifting evaporites (Casas et al., 2009; Soto et al., 2007).

In the Catalan Coastal Ranges, both Early Triassic and Late Jurassic-Early Cretaceous extensional faults were recognized (Gómez \& Guimerà, 1999; Salas et al., 2001), the latter mostly affecting the southern part of the studied transects. The main décollement (Mid-Triassic in age) is likely prerift to the south but syn-rift to postrift to the North, where it was less disrupted by extensional features at the time when convergence began (Figure 13d), therefore favoring the northward propagation of Triassic-detached thrusting.

Nevertheless, the lateral continuity of the units hosting the weak décollements does not necessarily ensure development of thin-skinned tectonics structures, since it also depends upon the effectiveness of the décollement itself. Effectiveness is mostly controlled by lithology and thickness changes in the "potential" décollements, although other factors such as the deformation velocity or the thickness of the overlying units can also play an important role on the activation or deactivation of a priori favorable evaporitic décollements (Santolaria et al., 2015). In the Eastern North Branch of the Iberian Range, North of the Sierra de Arcos thrust, Triassic evaporites are still present at depth but they are not an effective décollement and basement-involved structures dominate over pure thin-skinned thrusting.

\subsection{Horizontal Shortening Estimates Across the Study Area}

The cross sections presented in this study run roughly perpendicular to the arched strike of geological structures but at variable angles to the main $\mathrm{N} 010^{\circ} \mathrm{E}$ tectonic transport direction (Figure 4): Cross Sections 3 and 4 are subparallel, whereas Cross Sections 2 and 5 display a small obliquity that becomes stronger in Cross Sections 1, 6, and 7. Their restoration allows the estimation of horizontal shortening values that equal the total shortening when section traces are subparallel to the main shortening direction (Linking Zone). Nevertheless, these restorations underestimate shortening values where sections traces are oblique to the main transport direction (North Branch of the Iberian Range and Catalan Coastal Ranges) and moderate to important shortening takes place out-of-plane of the cross sections. Shortening underestimates caused by the obliquity of the transport direction (Cooper, 1983) and/or the occurrence of vertical axis rotations (as it is the case in some sectors of the North Branch of the Iberian Range; Pastor-Galán et al., 2018) may be later on corrected using existent approaches (Pueyo et al., 2004).

Taking that into account, restored cross sections in the study area allow the estimation of horizontal shortening values that are strongly variable across the eastern North Branch of the Iberian Range $(\sim 11 \mathrm{~km}$ in Cross Section 1, Figure 13a, and $\sim 3 \mathrm{~km}$ along Cross Section 2). These values roughly indicate an eastward shortening decrease in the study area that is in agreement with recent paleomagnetic investigations revealing moderate clockwise rotations in the North Branch ( $22^{\circ}$ clockwise; Pastor-Galán et al., 2018, to the west of the study area). These magnitudes will have a negligible impact in the shortening estimates (Oliva-Urcia \& Pueyo, 2019; Sussman et al., 2012). Conversely, horizontal shortening estimates are approximately constant in the Linking Zone (between 11 and $8 \mathrm{~km}$ ). These values represent a $\approx 10-15 \%$ of the total shortening in the Iberian Range (75 km; Salas et al., 2001) and are in good agreement with previously published shortening estimates: Nebot and Guimerà (2016a) calculated a shortening ranging between 10.5 and $11.2 \mathrm{~km}$ across two profiles located between Cross Section 3 (Figure 13b, $11 \mathrm{~km}$ of shortening) and Cross Section 5 (Figure 13c, $8 \mathrm{~km}$ of shortening) from the present study. Lower horizontal shortening estimates ( $\sim 3$ to 5 $\mathrm{km}$ ) have been obtained across the southern Catalan Coastal Ranges. These shortening estimates should be considered as a minimum value for the compressional Cenozoic deformation since fault transport directions in the Catalan Coastal Ranges (Guimerà \& Alvaro, 1990; Marcén et al., 2018) are generally oblique to the direction of Cross Sections 6 and 7 (Figure 4). Considering the angle ( $\alpha$ ) between the strike of the main faults and the shortening direction $\left(30-35^{\circ}\right)$, an estimation of the actual shortening (Sreal) from the shortening measured perpendicular to the structures (Sperp; 3 to $5 \mathrm{~km}$ ) can be estimated from (Cooper, 1983):

Sreal $=\operatorname{Sperp} / \sin \alpha$ 
Using this expression (as considered in de Vicente et al., 2009), shortening parallel in the N010 ${ }^{\circ} \mathrm{E}$ direction in Cross Sections 6 and 7 would amount 5 to $10 \mathrm{~km}$, these values becoming closer to those inferred in the Linking Zone.

\section{Conclusions}

We have carried out a geophysical and structural study at the transition between the Catalan Coastal Range and the Iberian Range. Our analysis merges surface and well data, a new gravity survey, and density measurements to regionally constrain the geometry of both the Paleozoic basement and the Mesozoic cover units. New data are set out in their tectonic frame through (i) regional-scale Bouguer and residual Bouguer anomaly maps and (ii) a set of seven serial, balanced cross sections that extend along-strike through the eastern North Branch (eastern Iberian Range), the Linking Zone, and the southern Catalan Coastal Ranges.

The residual Bouguer anomalies are NW-SE and NNE-SSW striking in the North Branch of the Iberian range and the southern Catalan Coastal Ranges, respectively, following the strike of main structures. A more complex pattern has been defined for the Linking Zone (derived from the interference between the Iberian and Catalan trends) with contours that locally run oblique or perpendicular to the structures. We have found a good agreement between positive residual gravity anomalies and basement antiforms whereas Mesozoic cover synclines, Triassic-detached structures and Neogene-Quaternary extensional basins correlate with areas of relative negative anomalies of varied wavelengths. The results of gravity modeling reveal that this technique is especially useful for constraining basement geometries both in the Iberian and Catalan Coastal Ranges domains and below the subhorizontal Cenozoic infill of the Ebro basin.

\section{Acknowledgments}

This study has been supported by the Instituto para la Reestructuración de la Minería del Carbón y el Desarrollo Alternativo de las Comarcas Mineras Ministry of Energy and Industry, Spain. Additional support has also come from the DR3AM and SALTCRES Projects (CGL2014-54118) from the Science National Plan of Spain (MINECO). The authors also acknowledge Midland Valley Exploration for providing Move software academic licenses. The contribution of Jose María Llorente, Agustín González, and Israel Pérez was essential for the acquisition of the geophysical data and the density measurements. The financial support of the Aragonian Goberment is also acknowledged (Applied Geology Group-GeoAp, E01_17R). The data used in this work can be found in the manuscript itself or in previous works listed in the references. Elevation reference data from the Instituto Geográfico Nacional (http://www.ign.es/ign/main/index. do) were used in the gravity processing as well as digital terrain models from the Spanish Army Geographical Survey (http://www.ejercito.mde.es/unidades/ Madrid/ceget/). Geological maps are available at the IGME website (http:// info.igme.es/cartografiadigital/), whereas well data from the Water Authority (CHE) are accessible at the IBER website (http://iber.chebro.es/ sitebro/sitebro.aspx?hydrogeoebro). We honestly thank the careful and constructive review done by B. Ábalos and G. de Vicente that helped us to improve this manuscript.
Cross sections show along-strike changing geometries and shortening values. We obtained the higher shortening and stronger lateral changes in the eastern North Branch of the Iberian Range where basementinvolved structures dominate, and subordinate thin-skinned folds and thrusts are moderately decoupled from the basement. In the Linking Zone, approximately constant shortening values were defined and cross sections depict a wide thrust wedge bounded to the north and to the south by basement structures that "isolate" a cover-detached thrust system between them (the Portalrubio-Vandellòs thrust system). The thinskinned thrust system shows an arcuate pattern in map view and changes strike sharply to the east, probably due to changes in the main décollement and/or in the strike of the dominant basement faults. The easternmost profiles traverse the southern Catalan Coastal Ranges where contraction was at a great extent accommodated through strike-slip motions. Basement-involved structures dominate, defining a thrust wedge that partly overlaps with the lateral continuation of the thin-skinned Portalrubio-Vandellòs thrust system.

Our results emphasize a strong control from Late Jurassic-Early Cretaceous structures on the contractional geometry of the study area. On the one hand, the strike of the structural inheritance is at the origin for the obliquity between the regional shortening direction and the tectonic grain, which is a first-order factor defining the geometry of the growing thrust systems. On the other hand, Jurassic-Cretaceous extensional tectonics probably promoted the disruption of the main Triassic décollements in the study area and largely hindered the development of thin-skinned structures within the inverted basin domains, whereas thinskinned thrusting was favorably developed in the footwall of the main faults limiting the Late JurassicEarly Cretaceous basins.

\section{References}

Aguilar, M. J., Ramírez del Pozo, J., \& Oriol Riba, A. (1971). Algunas precisiones sobre la sedimentación y la paleoecología del Cretácico Inferior de la zona de Utrillas-Villaroya de los Pinares (Teruel). Estudios Geológicos, 27, 497-512.

Almela-Samper, A., Mansilla Izquierdo, H., Quintero Amador, I., \& Gómez Nogueroles, E. (1975). Oliete (493). Mapa Geológico de España 1:50000, hoja 493 (Oliete). IGME, Madrid.

Alvaro, M., del Villar, R. C., \& Vegas, R. (1979). Un modelo de evolución geotectónica para la Cadena Celtibérica. Acta Geologica Hispánica, 14(1), 172-177.

Anadón Monzón, P., Colombo, F., Esteban, M., Marzo, M., Robles, S., Santanach, P., \& Sugrañes, L. S. (1979). Evolución tectonoestratigráfica de los Catalánides. Acta Geologica Hispánica, 1979(14), 242-270.

Anadón, P., Cabrera, L., Guimerà, J., \& Santanach, P. (1985). Paleogene strike-slip deformation and sedimentation along the southeastern margin of the Ebro Basin. United States: Special Publications of SEPM.

Anadón, P., \& Moissenet, E. (1996). Neogene basins in the Eastern Iberian Range. Tertiary Basins of Spain: The stratigraphic record of crustal kinematics, 6, 68. 
Arasa-Tuliesa, A., \& Cabrera-Pérez, L. (2018). Neogene-Quaternary onshore record in the lower Ebro River incised palaeovalley (Catalan Coastal Range, NE Iberia). Geologica Acta, 16(3), 265-292.

Arche, A., \& López-Gómez, J. (1996). Origin of the Permian-Triassic Iberian basin, central-eastern Spain. Tectonophysics, 266(1-4), 443-464 https://doi.org/10.1016/S0040-1951(96)00202-8

Aurell, M., Soria, A. R., Bádenas, B., Liesa, C. L., Canudo, J. I., Gasca, J. M., et al. (2018). Barremian synrift sedimentation in the Oliete subbasin (Iberian Basin, Spain): Palaeogeographical evolution and distribution of vertebrate remains. Journal of Iberian Geology, 44(2), 285-308. https://doi.org/10.1007/s41513-018-0057-3

Ayala, C., Bohoyo, F., Maestro, A., Reguera, M. I., Torne, M., Rubio, F., \& García-Lobón, J. L. (2016). Updated Bouguer anomalies of the Iberian Peninsula: A new perspective to interpret the regional geology. Journal of Maps, 12(5), 1089-1092. https://doi.org/10.1080/ 17445647.2015.1126538

Ayora, C., Soler, A., \& Melgarejo, J. C. (1990). The Hercynian ore deposits from the Catalonian Coastal Ranges. Acta Geologica Hispánica, 25, 65-73.

Beltrán Cabrera, F.J., Lanaja, J.M., \& Ríos Aragüés, L.M., (1978). Albalate del Arzobispo (468). Mapa Geológico de España 1:50000, hoja 468 (Albalate del Arzobispo). IGME, Madrid.

Bott, M. H. P., \& Masson-Smith, D. (1960). A gravity survey of the Criffell granodiorite and the New Red Sandstone deposits near Dumfries. Proceedings of the Yorkshire Geological Society, 32(3), 317-332. https://doi.org/10.1144/pygs.32.3.317

Boyer, S. E., \& Elliott, D. (1982). Thrust systems. AAPG Bulletin, 66(9), 1196-1230.

Butler, R. W. (1982). The terminology of structures in thrust belts. Journal of Structural Geology, 4(3), 239-245. https://doi.org/10.1016/ 0191-8141(82)90011-6

Calcagno, P., Chilès, J. P., Courrioux, G., \& Guillen, A. (2008). Geological modelling from field data and geological knowledge: Part I. Modelling method coupling 3D potential-field interpolation and geological rules. Physics of the Earth and Planetary Interiors, 171(1-4), 147-157. https://doi.org/10.1016/j.pepi.2008.06.013

Calvín, P., Casas-Sainz, A. M., Villalaín, J. J., \& Moussaid, B. (2017). Diachronous folding and cleavage in an intraplate setting (Central High Atlas, Morocco) determined through the study of remagnetizations. Journal of Structural Geology, 97, 144-160. https://doi.org/ 10.1016/j.jsg.2017.02.009

Canérot, J. (1974). Recherches géologiques aux confins des chaînes ibérique et catalane (Espagne). Doctoral dissertation, Laboratoire de géologie de l'Université Paul Sabatier.

Canérot, J., Crespo Zamorano, A., \& Navarro Vazquez, D. (1977). Montalbán (518). Mapa Geológico de España 1:50000, hoja 519 (Montalbán). IGME, Madrid.

Casas, A. M., Cortés, A. L., Liesa, C. L., Meléndez, A., \& Soria, A. R. (1997). Estructura del borde N. De la Cordillera Ibérica entre la Sierra de Arcos y el anticlinal de Montalbán. The structure of the norherrn margin of Iberian Range between the Sierra de Arcos and the Montalbán anticline. Cuadernos de Geología Ibérica, 23, 243-268.

Casas, A. M., Gapais, D., Nalpas, T., Besnard, K., \& Román-Berdiel, T. (2001). Analogue models of transpressive systems. Journal of Structural Geology, 23(5), 733-743. https://doi.org/10.1016/S0191-8141(00)00153-X

Casas, A. M., Villalaín, J. J., Soto, R., Gil-Imaz, A., Del Río, P., \& Fernández, G. (2009). Multidisciplinary approach to an extensional syncline model for the Mesozoic Cameros Basin (N Spain). Tectonophysics, 470(1-2), 3-20. https://doi.org/10.1016/j.tecto.2008.04.020

Casas-Sainz, A.M., (1992). El frente Norte de las Sierras de Cameros: Estructuras cabalgantes y campos de esfuerzos. Zubia, Monográfico 4 , Instituto de Estudios Riojanos, Logroño, 219 p.

Casas-Sainz, A. M., \& De Vicente, G. (2009). On the tectonic origin of Iberian topography. Tectonophysics, 474(1-2), 214-235. https://doi. org/10.1016/j.tecto.2009.01.030

Cook, F. A., \& Varsek, J. L. (1994). Orogen-scale decollements. Reviews of Geophysics, 32(1), 37-60. https://doi.org/10.1029/ 93RG02515

Cooper, M. A. (1983). The calculation of bulk strain in oblique and inclined balanced sections. Journal of Structural Geology, 5(2), 161-165. https://doi.org/10.1016/0191-8141(83)90041-X

Coward, M. P. (1994). Inversion tectonics. In Continental Deformation, (pp. 289-304). Oxford: Pergamon.

Crespo Ramón, J. L., \& Michel, B. (1980). Estudio geológico de los yacimientos minerales del macizo catalán entre Bellmunt de Ciruana y Mola, Priorato (Tarragona). Stvdia Geologica Salmanticensia, 16, 123-149.

De Graciansky, P. C., Dardeau, G., Lemoine, M., \& Tricart, P. (1989). The inverted margin of the French Alps and foreland basin inversion. Geological Society, London, Special Publications, 44(1), 87-104. https://doi.org/10.1144/GSL.SP.1989.044.01.06

De Vicente, G. (2018). El registro geológico de las deformaciones alpinas en Iberia: partición de la deformación o fases tectónicas. Revista de la Sociedad Geológica de España, 31, 2.

De Vicente, G., Cunha, P. P., Muñoz-Martín, A., Cloetingh, S. A. P. L., Olaiz, A., \& Vegas, R. (2018). The Spanish-Portuguese Central System: An example of intense intraplate deformation and strain partitioning. Tectonics, 37(12), 4444-4469. https://doi.org/10.1029/ 2018TC005204

De Vicente, G., \& Vegas, R. (2009). Large-scale distributed deformation controlled topography along the western Africa-Eurasia limit: Tectonic constraints. Tectonophysics, 474(1-2), 124-143. https://doi.org/10.1016/j.tecto.2008.11.026

De Vicente, G., Vegas, R., Martín, A. M., Silva, P. G., Andriessen, P., Cloetingh, S. A. P. L., et al. (2007). Cenozoic thick-skinned deformation and topography evolution of the Spanish Central System. Global and Planetary Change, 58(1-4), 335-381. https://doi.org/10.1016/j. gloplacha.2006.11.042

De Vicente, G., Vegas, R., Muñoz-Martín, A., Van Wees, J. D., Casas-Sáinz, A., Sopeña, A., et al. (2009). Oblique strain partitioning and transpression on an inverted rift: The Castilian Branch of the Iberian Chain. Tectonophysics, 470(3-4), 224-242. https://doi.org/10.1016/j tecto.2008.11.003

Elming, S. Å. (1980). Density and magnetic properties of rocks in the Caledonides of Jämtland, Sweden. Geologiska Föreningen i Stockholm Förhandlingar, 102(4), 439-453. https://doi.org/10.1080/11035898009454499

Enrique, P. (1990). The Hercynian intrusive rocks of the Catalonian Coastal Ranges (NE Spain). Acta Geologica Hispánica, 25, 39-64.

Fontboté, J. M., Guimerà, J., Roca, E., Sàbat, F., Santanach, P., \& Fernández-Ortigosa, F. (1990). The Cenozoic geodynamic evolution of the Valencia trough (western Mediterranean). Revista de la Sociedad Geológica de España, 3(3-4), 249-259.

García de Domingo, A., Lopez Olmedo, F., \& Barnolas, A. (1982a). Beceite (521). Mapa Geológico de España 1:50000, hoja 521 (Beceite). IGME, Madrid.

García de Domingo, A., Lopez Olmedo, F., \& Barnolas, A. (1982b). Horta de San Juan (496). Mapa Geológico de España 1:50000, hoja 492 (Horta de San Juan). IGME, Madrid. 
García-Lobón, J. L., Rey-Moral, C., Ayala, C., Martín-Parra, L. M., Matas, J., \& Reguera, M. I. (2014). Regional structure of the southern segment of Central Iberian Zone (Spanish Variscan Belt) interpreted from potential field images and $2.5 \mathrm{D}$ modelling of Alcudia gravity transect. Tectonophysics, 614, 185-202. https://doi.org/10.1016/j.tecto.2013.12.005

Goleby, B. R., Shaw, R. D., Wright, C., Kennett, B. L., \& Lambeck, K. (1989). Geophysical evidence for 'thick-skinned' crustal deformation in central Australia. Nature, 337(6205), 325-330. https://doi.org/10.1038/337325a0

Gómez, M., \& Guimerà, J. (1999). Estructura alpina de la Serra de Miramar y del NE de las Muntanyes de Prades (Cadana Costero Catalana). Revista de la Sociedad Geológica de España, 12, 405-418.

González, A. (1989). Análisis tectosedimentario del terciario del borde SE de la Depresión del Ebro (sector bajo-aragonés) y de las cubetas ibéricas marginales. Tesis Univ. Zaragoza. 507

Guillen, A., Courrioux, G., Calcagno, P., Lane, R., Lees, T., \& McInerney, P. (2004) Constrained gravity 3D litho-inversion applied to Broken Hill: in Conference Abstracts, ASEG 17th Geophysical Conference and Exhibition, Sydney.

Guimerà, J. (1983). Évolution de la deformation alpine dans le NE de la Chaîne Ibérique et dans la Chaîne Côtière Catalane. Comptesrendus de l'Académie des sciences. Série 2, Mécanique-physique, chimie, sciences de l'univers, sciences de la terre, 297(5), 425-430.

Guimerà, J. (1988). Estudi estructural de l'enllaç entre la Serralada Ibèrica i la Serralada Costanera Catalana. Universitat de Barcelona.

Guimerà, J., \& Alvaro, M. (1990). Structure et évolution de la compression alpine dans la Chaîne Ibérique et la Chaîne côtière catalane (Espagne). Bulletin de la Société géologique de France, 6(2), 339-348.

Guimerà, J., González, A., \& Pérez, A. (1990). Evolucion del cabalgamiento de la Muela de Montalban (Cordillera Iberica, Teruel). Geogaceta, 8, 47-49.

Guimerà, J., Mas, R., \& Alonso, Á. (2004). Intraplate deformation in the NW Iberian Chain: Mesozoic extension and Tertiary contractional inversion. Journal of the Geological Society, 161(2), 291-303. https://doi.org/10.1144/0016-764903-055

Guimerà, J., Rivero, L., Salas, R., \& Casas, A. (2016). Moho depth inferred from gravity and topography in an intraplate area (Iberian Chain). Tectonophysics, 666, 134-143. https://doi.org/10.1016/j.tecto.2015.10.021

Guiraud, M., \& Séguret, M. (1984). Releasing solitary overstep model for the Late Jurassic - Early Cretaceous (Wealdien) Soria strikeslip basin (North Spain). In K. T. Biddle, \& N. Cristhie-Blick (Eds.), Strike-slip deformation, basin formation and sedimentation, (Vol. 37, pp. 159-175). SEPM, San Antonio: Spec. Publ.

Gutiérrez-Marco, J. C. (2004). El Basamento prealpino, Cordilleras Ibérica y Costero-Catalana. In J. A. Vera (Ed.), Geología de España (pp. 470-484). Spain: Sociedad Geológica de España, Igme.

Hammer, S. (1939). Terrain corrections for gravimeter stations. Geophysics, 4(3), 184-194. https://doi.org/10.1190/1.1440495

Hatherton, T., \& Leopard, A. E. (1964). The densities of New Zealand rocks. New Zealand Journal of Geology and Geophysics, 7(3), 605-625. https://doi.org/10.1080/00288306.1964.10422108

Huiqi, L., McClay, K. R., \& Powell, D. (1992). Physical models of thrust wedges. In Thrust tectonics, (pp. 71-81). Dordrecht: Springer.

IGME, 2004. Geological Map of Spain, 1:2,000,000 in scale. IGME, Madrid

Institut Cartogràfic i Geològic de Catalunya (ICGC) (2006). Base geològica de Catalunya: Síntesi geològica a partir del Mapa Geológico de España 1:50000, serie Magna.

Izquierdo-Llavall, E., Roca, E., Xie, H., Pla, O., Muñoz, J. A., Rowan, M. G., et al. (2018). Influence of overlapping décollements, syntectonic sedimentation, and structural inheritance in the evolution of a contractional system: The central Kuqa fold-and-thrust belt (Tian Shan Mountains, NW China). Tectonics, 37(8), 2608-2632. https://doi.org/10.1029/2017TC004928

Juez-Larré, J., \& Andriessen, P. A. M. (2002). Post Late Paleozoic tectonism in the southern Catalan Coastal Ranges (NE Spain), assessed by apatite fission track analysis. Tectonophysics, 349(1-4), 113-129. https://doi.org/10.1016/S0040-1951(02)00049-5

Julià, R., \& Santanach, P. (1984). Estructuras en la salbanda de falla paleógena de la falla del Vallés-Penedés (Cadenas Costeras Catalanas): Su relación con el deslizamiento de la falla. I Congreso Español de Geología. In I Congreso Español de Geología, (pp. 47-59). Spain: Ilustre Colegio Oficial de Geólogos.

Julivert, M., \& Durán, H. (1990). The Hercynian structure of the Catalonian Coastal Ranges (NE Spain). Acta Geologica Hispánica, 25, $13-21$.

Lanaja, J. M. (1987). Contribución de la exploración petrolífera al conocimiento de la geología de España, (p. 465). Madrid: Instituto Geológico y Minero de España (IGME). ISBN: 84-7474-398-2

Liesa, C. L. (2000). Fracturación y campos de esfuerzos compresivos alpinos en la Cordillera Ibérica y el NE peninsular, (p. 760). Tesis Doctoral: Univ. Zaragoza.

Liesa, C. L., \& Simón, J. L. (2007). A Probabilistic approach for identifying independent remote compressions in an intraplate region: The Iberian Chain (Spain). Mathematical Geology, 39(3), 337-348. https://doi.org/10.1007/s11004-007-9084-x

Liesa, C. L., Soria, A. R., Meléndez, N., \& Meléndez, A. (2006). Extensional fault control on the sedimentation patterns in a continental rift basin: El Castellar Formation, Galve sub-basin, Spain. Journal of the Geological Society, 163(3), 487-498. https://doi.org/10.1144/0016764904-169

López- Olmedo, F., García Rojo, E., Martínez Cano, M., Pérez Ruiz, J., García-Brazales Gómez, R., \& Monzón Lara, P. (2011). Mapa Geológico Digital continuo E. 1: 50.000, Zona Ibérica (Zona-1700). In J. Navas (Ed.), GEODE. Mapa Geológico Digital continuo de España. Sistema de Información Geológica Continua: SIGECO: IGME. Available in: http://cuarzo.igme.es/sigeco/ default.htm

Marcén, M., Casas-Sainz, A. M., Román-Berdiel, T., Griera, A., Santanach, P., Pocoví, A., et al. (2018). Multiple movements recorded in a crustal weakness zone in NE Iberia: The Vallès-Penedès Fault revisited. Journal of Geodynamics, 121, 96-114. https://doi.org/10.1016/j. jog.2018.07.003

Marín, P., \& Duval, B. (1976). Castelserás (495). Mapa Geológico de España 1:50000, hoja 495 (Castelserás). Madrid: IGME.

Martín, L., Leyva, F., \& Canerot, J. (1972). Morella (545). Mapa Geológico de España 1:50000, hoja 545 (Morella). Madrid: IGME.

Martínez-Durán, 1997. Estratigrafía secuencial y sedimentología del Cretácico Superior (Cenomaniense Superior-Turoniense Inferior) de la Cordillera Ibérica Central. Análisis de cuenca. Unpublished MSc Thesis University of Zaragoza. 162 pp.

Masana, E. (1994). Neotectonic features of the Catalan Coastel Ranges, Northeastern Spain. Acta Geologica Hispánica, 29(2), 107-121.

McClay, K. R., Whitehouse, P. S., Dooley, T., \& Richards, M. (2004). 3D evolution of fold and thrust belts formed by oblique convergence. Marine and Petroleum Geology, 21(7), 857-877. https://doi.org/10.1016/j.marpetgeo.2004.03.009

McQuarrie, N. (2004). Crustal scale geometry of the Zagros fold-thrust belt, Iran. Journal of Structural Geology, 26(3), 519-535. https://doi. org/10.1016/j.jsg.2003.08.009

Mediato, J. F., García-Crespo, J., Izquierdo, E., García-Lobón, J. L., Ayala, C., Pueyo, E. L., \& Molinero, R. (2017). Three-dimensional reconstruction of the Caspe Geological Structure (Spain) for evaluation as a potential $\mathrm{CO}_{2}$ storage site. Energy Procedia, 114, 4486-4493. https://doi.org/10.1016/j.egypro.2017.03.1608 
Mégard, F. (1984). The Andean orogenic period and its major structures in central and northern Peru. Journal of the Geological Society, 141(5), 893-900. https://doi.org/10.1144/gsjgs.141.5.0893

Mitra, S. (1986). Duplex structures and imbricate thrust systems: Geometry, structural position, and hydrocarbon potential. $A A P G$ Bulletin, 70(9), 1087-1112.

Muñoz, A. (1992b). Análisis tectosedimentario del Terciario del sector occidental de la Cuenca del Ebro. Ciencias de la Tierra, 15, 347.

Muñoz, J. A. (1992a). Evolution of a continental collision belt: ECORS-Pyrenees crustal balanced cross-section. In Thrust tectonics, (pp 235-246). Dordrecht: Springer.

Nebot, M., \& Guimerà, J. (2016a). Structure of an inverted basin from subsurface and field data: the Late Jurassic-Early Cretaceous Maestrat Basin (Iberian Chain). Geologica Acta, 2016(14), 155-177.

Nebot, M., \& Guimerà, J. (2016b). Kinematic evolution of a fold-and-thrust belt developed during basin inversion: the Mesozoic Maestrat basin, E Iberian Chain. Geological Magazine, 155(3), 1-11.

Nemčok, M., Mora, A., \& Cosgrove, J. W. (Eds.) (2013, October). Thick-skin-dominated orogens: From initial inversion to full accretion. UK: Geological Society of London.

Oliva-Urcia, B., \& Pueyo, E. L. (2019). Paleomagnetism in structural geology and tectonics. In Teaching methodologies in structural geology and tectonics, (pp. 55-121). Singapore: Springer.

Orche-García, E., Robles Orozco, S., \& Rosell Sanuy, J. (1978). Perello (497). Mapa Geológico de España 1:50000, hoja 497 (Perello). Madrid: IGME.

Ortí, F., Salvany, J. M., Rosell, L., Castelltort, X., Inglès, M., \& Playà, E. (2018). Middle Triassic evaporite sedimentation in the Catalan basin: Implications for the paleogeographic evolution in the NE Iberian platform. Sedimentary Geology, 374, 158-178. https://doi.org/ 10.1016/j.sedgeo.2018.07.005

Pastor-Galán, D., Pueyo, E.l., Diederen, M., García-Lasanta, C., \& Langereis, C. G. (2018). Late Paleozoic Iberian orocline (s) and the missing shortening in the core of Pangea. Paleomagnetism from the Iberian Range. Tectonics, 37(10), 3877-3892. https://doi.org/ 10.1029/2018TC004978

Pérez, A. (1989). Estratigrafía y Sedimentología del Terciario del borde S de la Depresión del Ebro (sector riojano-aragonés) y cubetas de Muniesa y Montalbán, (p. 525). Zaragoza: Tesis Univ.

Pfiffner, O. A. (2006). Thick-skinned and thin-skinned styles of continental contraction. Special papers-Geological Society of America, 414, 153.

Pfiffner, O. A. (2014). Geology of the Alps. United States of America: John Wiley \& Sons.

Pfiffner, O. A. (2017). Thick-skinned and thin-skinned tectonics: A global perspective. Geosciences, 7(3), 71. https://doi.org/10.3390/ geosciences7030071

Plata, J. L. (1991). Programa CCT (cálculo de la corrección topográfica por el método de Hammer). Spain: Documento interno Área de Geofísica, IGME.

Plata Torres, J. L. (2009). Establecimiento de bases metodológicas para la obtención de cartografía gravimétrica 1:50.000. Aplicación a la modelización 2D y 3D en varias zonas de la Peninsula Iberica. Capítulo 3: Informe de Petrofísica. Instituto Geológico y Minero de España. Documento Interno Código: 64060. 113 pp + anexos. Retrieved October 9, 2015, from http://www.igme.es/sistemas_infor/ GeoBuscador/pagina_marcos.asp

Pueyo, E. L., Izquierdo-Llavall, E., Rodríguez-Pintó, A., Rey-Moral, C., Oliva-Urcia, B., Casas, A. M., et al. (2016). Petrophysical properties in the Iberian Range and surrounding areas (NE Spain): 1-density. Journal of Maps, 12(5), 836-844. https://doi.org/10.1080/ 17445647.2015.1084545

Pueyo, E. L., Pocoví, A., Millán, H., \& Sussman, A. (2004). Map-view models for correcting and calculating shortening estimates in rotated thrust fronts using paleomagnetic data. In A. Weil, \& A. Sussman (Eds.), Special Publication on Orogenic Curvature: Integrating Paleomagnetic and Structural Analyses, Geological Society of America Special Publication, (Vol. 383, pp. 57-71).

Ríos-Aragüés, L. M., Beltrán Cabrera, F. J., Lanaja, J. M., \& Gavaldón López, V. (1978). Muniesa (467). Mapa Geológico de España 1:50000 hoja 467 (Muniesa). Madrid: IGME.

Robador Moreno, A., Ramajo Cordero, J., Muñoz Jiménez, A., Pérez García, A., Luzón, A., Arenas Abad, C., \& González Rodríguez, A. (2011). Mapa Geológico Digital continuo E. 1:50.000, Zona Cuenca del Ebro (Zona-2700). In J. Navas (Ed.), GEODE. Mapa Geológico Digital continuo de España. Sistema de Información Geológica Continua: SIGECO: IGME. Available in: http://cuarzo.igme.es/sigeco/ default.htm

Roca, E., \& Guimerà, J. (1992). The Neogene structure of the eastern Iberian margin: structural constraints on the crustal evolution of the Valencia trough (western Mediterranean). Tectonophysics, 203(1-4), 203-218. https://doi.org/10.1016/0040-1951(92)90224-T

Roca, E., Guimerà, J., \& Salas, R. (1994). Mesozoic extensional tectonics in the southeast Iberian Chain. Geological Magazine, 131(2), 155-168. https://doi.org/10.1017/S0016756800010694

Rodríguez Fernández, L. R., López Olmedo, F., Oliveira, J. T., Medialdea, T., Terrinha, P., Matas, J., et al. (2014). In L. R. R. Fernández, \& J. T. Oliveira (Eds.), Mapa Geológico de España y Portugal a escala 1:1000000. Spain/Portugal: IGME-LNEG. ISBN: 978-84-7840949-5

Rodríguez-López, J. P., Meléndez, N., Soria, A. R., \& de Boer, P. L. (2009). Reinterpretación estratigráfica y sedimentológica de las formaciones Escucha y Utrillas de la Cordillera Ibérica. Revista de la Sociedad Geológica de España, 22(3-4), 163-219.

Salas, R., \& Casas, A. (1993). Mesozoic extensional tectonics, stratigraphy and crustal evolution during the Alpine cycle of the eastern Iberian basin. Tectonophysics, 228(1-2), 33-55. https://doi.org/10.1016/0040-1951(93)90213-4

Salas, R., \& Guimerà, J. (1996). Rasgos estructurales principales de la cuenca cretácica inferior del Maestrazgo (Cordillera Ibérica oriental). Geogaceta, 20, 7.

Salas, R., \& Guimerà, J. (1997). Estructura y estratigrafía secuencial de la cuenca del Maestrazgo durante la etapa de rift Jurásica superiorCretácica inferior (Cordillera Ibérica Oriental). Boletín Geológico y Minero, 108(4-5), 65-74.

Salas, R., Guimerà, J., Mas, R., Martín-Closas, C., Meléndez, A., \& Alonso, A. (2001). Evolution of the Mesozoic central Iberian Rift System and its Cainozoic inversion (Iberian chain). Peri-Tethys Memoir, 6, 145-185.

San Román, J., \& Aurell, M. (1992). Palaeogeographical significance of the Triassic-Jurassic unconformity in the north Iberian basin (Sierra del Moncayo, Spain). Palaeogeography, Palaeoclimatology, Palaeoecology, 99(1-2), 101-117. https://doi.org/10.1016/00310182(92)90009-T

Santolaria, P., Vendeville, B. C., Graveleau, F., Soto, R., \& Casas-Sainz, A. (2015). Double evaporitic décollements: Influence of pinch-out overlapping in experimental thrust wedges. Journal of Structural Geology, 76, 35-51. https://doi.org/10.1016/j.jsg.2015.04.002

Sanz de Galdeano, C. S. (1990). Geologic evolution of the Betic Cordilleras in the Western Mediterranean, Miocene to the present Tectonophysics, 172(1-2), 107-119. https://doi.org/10.1016/0040-1951(90)90062-D 
Seillé, H., Salas, R., Pous, J., Guimerà, J., Gallart, J., Torne, M., et al. (2015). Crustal structure of an intraplate thrust belt: The Iberian Chain revealed by wide-angle seismic, magnetotelluric soundings and gravity data. Tectonophysics, 663, 339-353. https://doi.org/10.1016/j. tecto.2015.08.027

Simón Gómez, J.L. (1984). Compresión y distensión alpinas en la Cadena Ibérica oriental» (Doctoral dissertation, Tesis Doctoral, Univ. Zaragoza. Pub]. Instituto de Estudios Turolenses, Teruel).

Sopeña, A., López, J., Arche, A., Pérez-Arlucea, M., Ramos, A., Virgili, C., \& Hernando, S. (1988). Permian and Triassic rift basins of the Iberian Peninsula. Developments in Geotectonics, 22, 757-786. https://doi.org/10.1016/B978-0-444-42903-2.50036-1

Soria, A.R., (1997). La sedimentación en las cuencas marginales del surco Ibérico durante el Cretácico inferior y su control estructural. Unpublished PhD Thesis, University of Zaragoza, 363 pp.

Soria, A. R., Meléndez, A., Aurell, M., Liesa, C. L., Meléndez, M. N., \& Gómez-Fernández, J. C. (2000). The Early Cretaceous of the Iberian Basin (northeastern Spain). In E. H. Gierlowski-Kordesch, \& K. R. Kelts (Eds.), Lake basins through space and time: AAPG Studies in Geology, (Vol. 46, pp. 257-262). United States: AAPG.

Soto, R., Casas-Sainz, A. M., \& Del Río, P. (2007). Geometry of half-grabens containing a mid-level viscous décollement. Basin Research, 19(3), 437-450. https://doi.org/10.1111/j.1365-2117.2007.00328.x

Sussman, A. J., Pueyo, E. L., Chase, C. G., Mitra, G., \& Weil, A. B. (2012). The impact of vertical-axis rotations on shortening estimates. Lithosphere, 4(5), 383-394. https://doi.org/10.1130/L177.1

Talwani, M., Worzel, J. L., \& Landisman, M. (1959). Rapid gravity computations for two dimensional bodies with application to the Mendocino submarine fracture zone. Journal of Geophysical Research, 64(1), 49-59. https://doi.org/10.1029/JZ064i001p00049

Teixell, A. (1988). Desarrollo de un anticlinorio por transpresión, aislando una cuenca sedimentaria marginal (borde oriental de la Cuenca del Ebro, Tarragona). Revista de la Sociedad Geológica de España, 1(1-2), 0229-0238.

Teixell, A., Arboleya, M. L., Julivert, M., \& Charroud, M. (2003). Tectonic shortening and topography in the central High Atlas (Morocco). Tectonics, 22(5), 1051. https://doi.org/10.1029/2002TC001460

Vigneresse, J. L. (1990). Use and misuse of geophysical data to determine the shape at depth of granitic intrusions. Geological Journal, 25(3-4), 249-260. https://doi.org/10.1002/gj.3350250308

Virgili, C., Sopeña, A., Ramos, A., Arche, A., \& Hernando, S. (1983). El relleno posthercínico y el comienzo de la sedimentación mesozoica Libro Jubilar JM Rios: Geologia de España, Instituto Geológico y Minero de España, 2, 25-36.

Williams, G. D., Powell, C. M., \& Cooper, M. A. (1989). Geometry and kinematics of inversion tectonics. Geological Society, London, Special Publications, 44(1), 3-15. https://doi.org/10.1144/GSL.SP.1989.044.01.02

Won, I. J., \& Bevis, M. (1987). Computing the gravitational and magnetic anomalies due to a polygon: Algorithms and Fortran subroutines. Geophysics, 52(2), 232-238. https://doi.org/10.1190/1.1442298 